\title{
A late Paleocene non-marine microflora from the interbasaltic coals of the Faeroe Islands, North Atlantic
}

\author{
JANE LUND
}

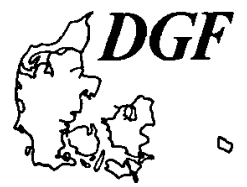

\begin{abstract}
Lund, J.: A late Paleocene non-marine microflora from the interbasaltic coals of the Faeroe Islands, North Atlantic. Bull. geol. Soc. Denmark, Vol. 37, pp. 181-203, Copenhagen, April 10th, 1989. https://doi.org/10.37570/bgsd-1988-37-14

Coals interbedded between basalts on Suduroy, Faeroe Islands contain a non-marine microflora characterized by the common presence of a Momipites-Caryapollenites complex, low numbers of bisaccate pollen and the absence of pollen of the Normapolles group. The assemblage is related to North American microfloras as shown by such species as Phaseoliidites stanleyi and Pesavis tagluensis. Based on the concurrent range of several species, the evolutionary level of pollen of Juglandaceae-like plants, and the quantitative composition of the assemblage, a late Paleocene age is probable. This dating is in accordance with a new magnetostratigraphic correlation herein proposed. The climate was humid and warm temper-ate. The coals are partly lacustrine. Replacement of "Alnus"- to "Sphagnum"-types probably shows a reduction of nutrients by regional leaching.
\end{abstract}

Jane Lund, Fr.-Hoffmann-Str. 8, D-3109 Wietze, West Germany, September 9th, 1988.

The volcanic sequence with interbedded coals occurring on the Faeroe Islands has been assigned to different ages in the literature. Based on regional geologic arguments, Rasmussen (1963) considered the sequence to be of Eocene to Oligocene age, whereas later radiometric datings (Tarling \& Gale 1968) implied an early Eocene to early Paleocene age. Waagstein, Hald, Jørgensen, Nielsen, Noe-Nygaard, Rasmussen \& Schönharting (1984) suggested a tentative magnetostratigraphic correlation, but did not comment on its relationship with chronostratigraphy. The implication of magnetostratigraphy for the dating of the Faeroe Islands basalts is discussed seperately below.

Preliminary palynologic studies of the Faeroe Islands coals by Laufeld (1965) pointed to an Eocene age. In Lund (1981 and 1983) the microflora of additional samples was briefly outlined and placed in the late Paleocene. The aim of this paper is to give a full account of the mentioned interbasaltic microflora and to elaborate on its age and paleoenvironment.

The stratigraphic term late Paleocene is used in accordance with Berggren, Kent \& Flynn (1985) to cover the interval between the Danian and the Ypresian and to correspond to the youngest NP4 to NP9 Zone in the nannoplankton zonation scheme of E. Martini. It is important to note that the late Paleocene, as used in this sense, includes the youngest Landenian/Sparnacian, in accordance with Curry, Adams, Boulter, Dilley, Eames, Funnell \& Wells (1978). Other authors (e.g. Krutzsch \& Vanhoorne 1977, Springhorn 1984) place the youngest Landenian/Sparnacian in the early Eocene.

\section{Geology}

The Faeroe Islands are a part of the North Atlantic basaltic province (fig. 1). The basaltic sequence on the Faeroe Islands is at least $5 \mathrm{~km}$ thick with $3 \mathrm{~km}$ exposed and $2 \mathrm{~km}$ known from drilling (Rasmussen \& Noe-Nygaard 1969, Waagstein et al. 1984). In the middle of this sequence, between the so-called lower and middle basalt series, a coal (ca. $1 \mathrm{~m}$ ) occurs overlain by up to 13 $\mathrm{m}$ of clay and tuffs. In addition, coal is known also from a slightly deeper level just below the topmost $20 \mathrm{~m}$ thick basalt layer of the lower basalt series (Rasmussen \& Noe-Nygaard 1969).

\section{Magnetostratigraphy}

The seabottom between Iceland and the Faeroe Islands was mapped for magnetic anomalies (Bott, Saxov, Talwani \& Thiede 1983). By this 


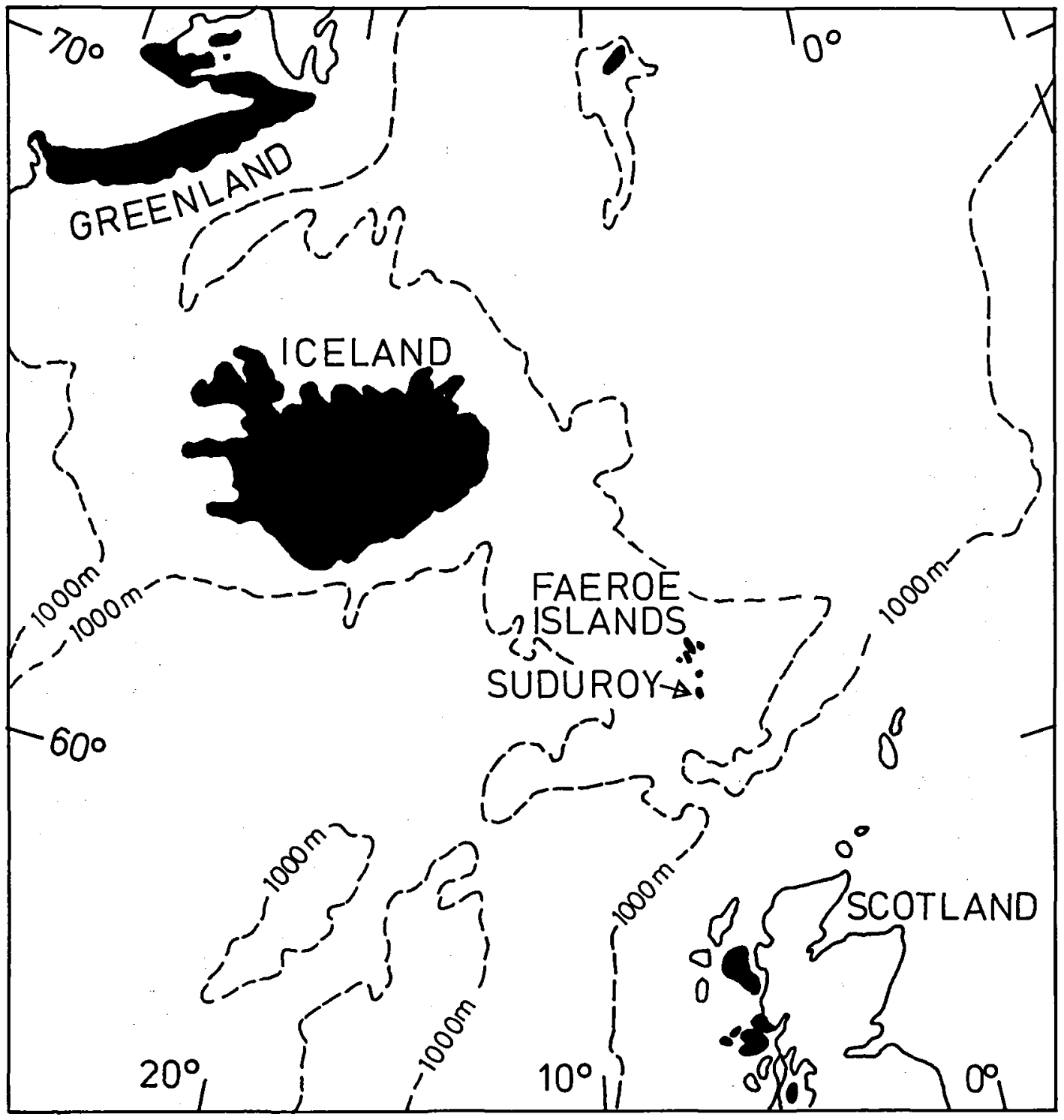

Fig. 1. Position of the Faeroe Islands locating Suduroy. Tertiary to Recent volcanics are shown in black.

mapping the Faeroe Islands were not tied in numbered sequence of Tertiary magnetic events, which correlate with the stratigraphic scheme (Eocene, Paleocene etc.) as shown here on fig. 2, and on fig. 4.7 in Harland, Cox, Llewellyn, Pickton, Smith \& Walters (1982).

According to Abrahamsen (1967 fig. 7) and Waagstein et al. (1984) the basalt sequence on the Faeroe Islands is magnetized in descending order: (a) $1600 \mathrm{~m}$ reverse, (b) $290 \mathrm{~m}$ normal, (c) $250 \mathrm{~m}$ reverse, (d) $360 \mathrm{~m}$ normal, and (e) ca. 2200 $\mathrm{m}$ tentatively reverse. The coals occur at the tran- sition between (a) and (b); (e) is known only from drilling with five short cores from $326 \mathrm{~m}-$ $2166 \mathrm{~m}$ below sea level. When these thicknesses are compared with the duration of the magnetic events as shown in Harland et al. (1982) the best fit is obtained when (a) is correlated with polarity $24 r$, (b) with 25 , (c) with $25 \mathrm{r}$, (d) with 26 , and (e) with 26r (fig. 2). As the Eocene-Paleocene boundary falls in the middle of polarity chron $24 r$, this implies that the coals are probably of late Paleocene age.

The herein proposed magnetostratigraphic cor- 
MAGNETOSTRATIGRAPHIC

TIME SCALE

(HARLAND ET AL. 1982)

FAEROE

ISLANDS

POLARITY OF

BASALT SERIES

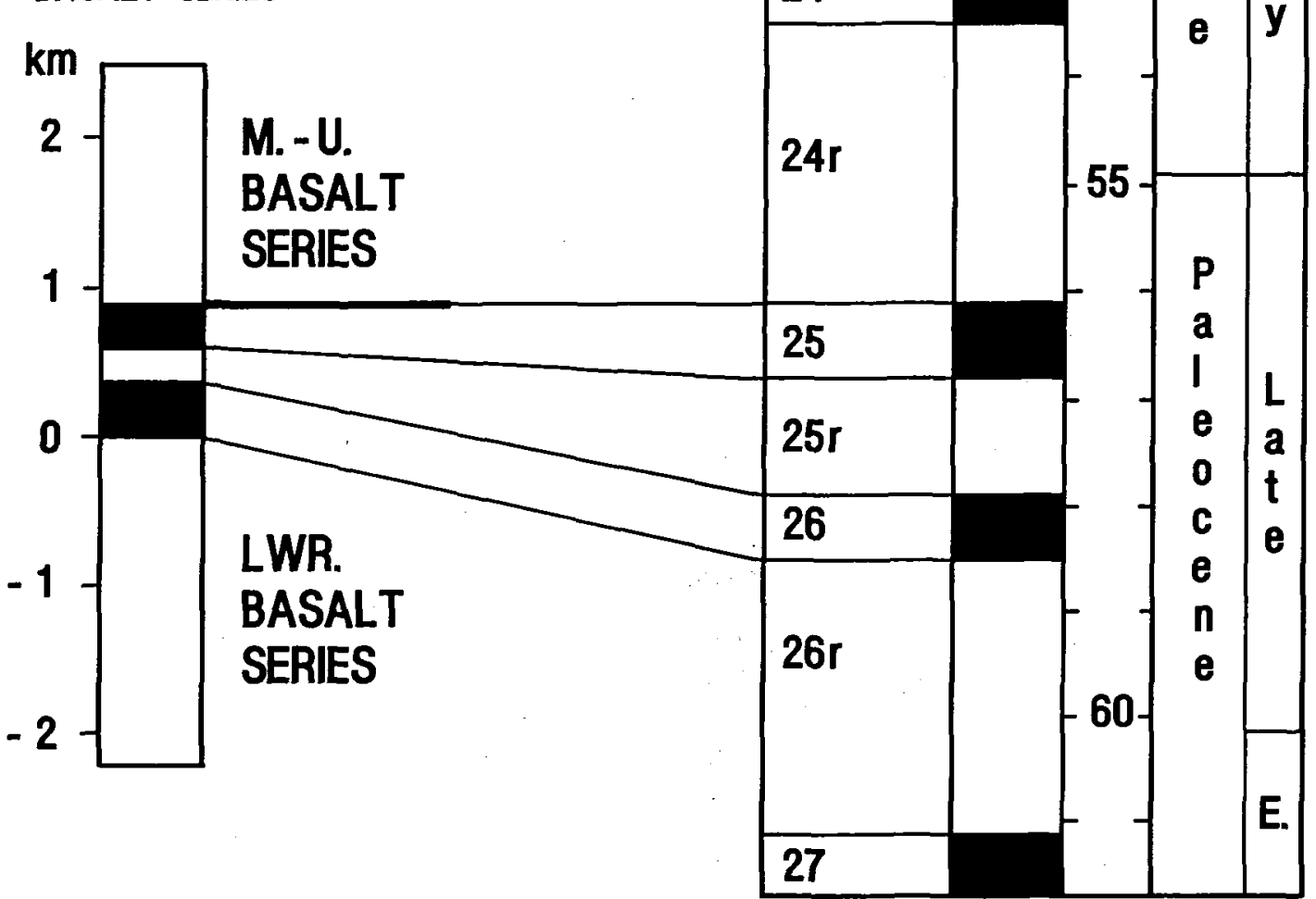

Fig. 2. Correlation of the Faeroe Islands basalt series and the magnetostratigraphic time scale. Polarity of the basalt series is after Abrahamsen (1967) and Waagstein et al. (1984).

relation does not fit with the provisional correlation proposed by Waagstein et al. (1984), who tentatively suggested that the thick lower reverse interval (e) was formed within the same reverse magnetic period as the East Greenland basalts which had been correlated with anomaly $24-25$.
This would imply a correlation of (a) with 23 r or perhaps even with $22 r$.

However, a correlation of (a) with $23 \mathrm{r}$, which is of short duration, is unlikely due to the considerable thickness of (a). A correlation of (a) with $22 r$, which is of longer duration, seems excluded 


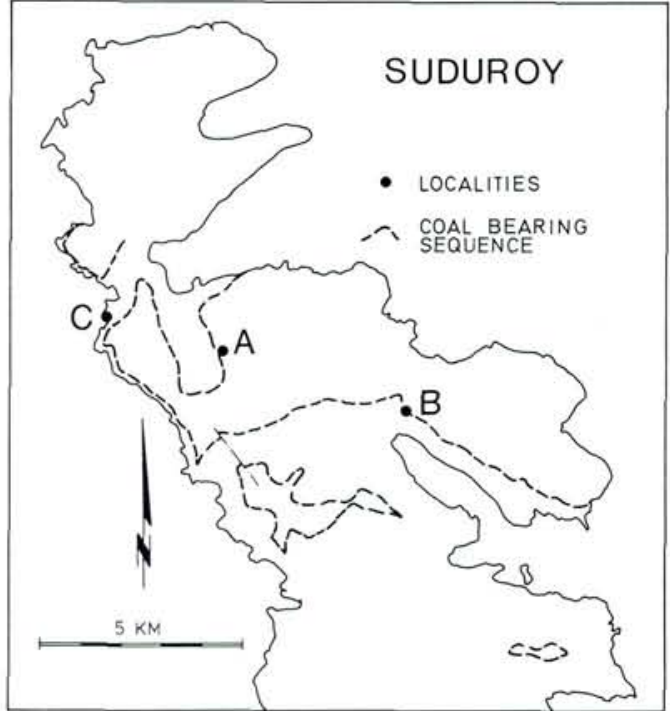

Fig. 3. Microflora yielding localities A, B, and C from Suduroy, Faeroe Islands.

by the map of Bott et al. (1983) according to which $22 \mathrm{r}$ at the sea bottom is to be expected about $200 \mathrm{~km}$ to the NW of the Faeroe Islands. The upper thick reverse interval (a) is therefore considered to correlate with $24 \mathrm{r}$. This implies that the lower thick reverse interval (e) should be correlated with $26 \mathrm{r}$ which is the next underlying reversely magnetized interval of long duration (fig. 2).

Nevertheless, as there are different opinions on the magnetostratigraphy of the Faeroe Islands, independent dating is needed. In the following such an independent biostratigraphic dating is presented utilizing palynology. This dating is in accordance with Lund (1983).

\section{Material}

The samples used for the palynological study were collected at three localities $(\mathrm{A}, \mathrm{B}$, and $\mathrm{C})$ from the northern part of Suduroy (fig. 3). Localities $\mathrm{A}$ and $\mathrm{B}$ represent the coal bearing sequence at the junction between the lower and the middle basalt series, whereas locality $\mathrm{C}$ exposes coaly clay just below the topmost basalt layer of the lower basalt series.

The most complete section was obtained from

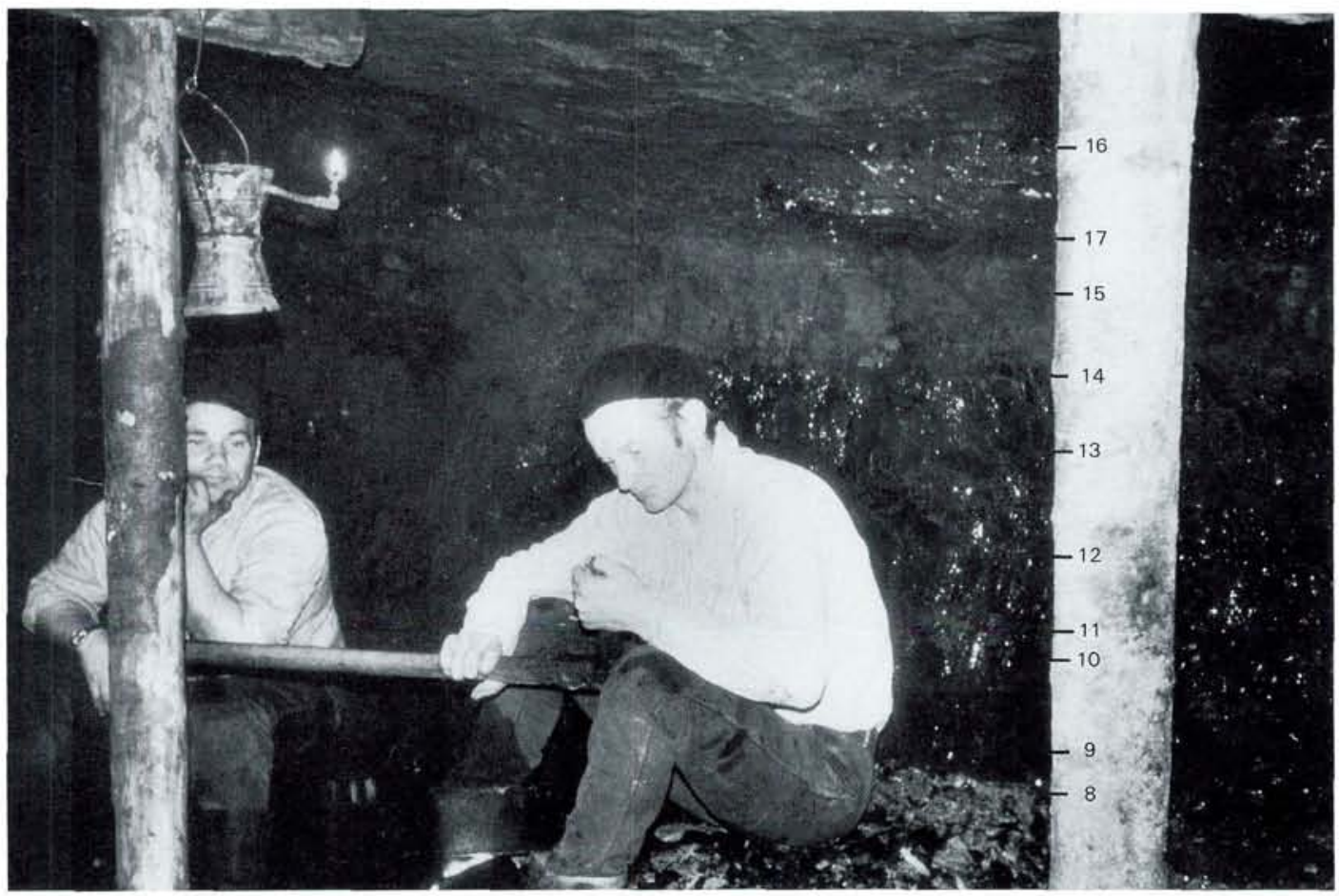

Fig. 4. The main coal seam at locality A, the only shaft still mined when the photograph was taken in 1975 . The position of samples $8-17$ is indicated. The subdivision of the coal is shown on fig. 5 . 


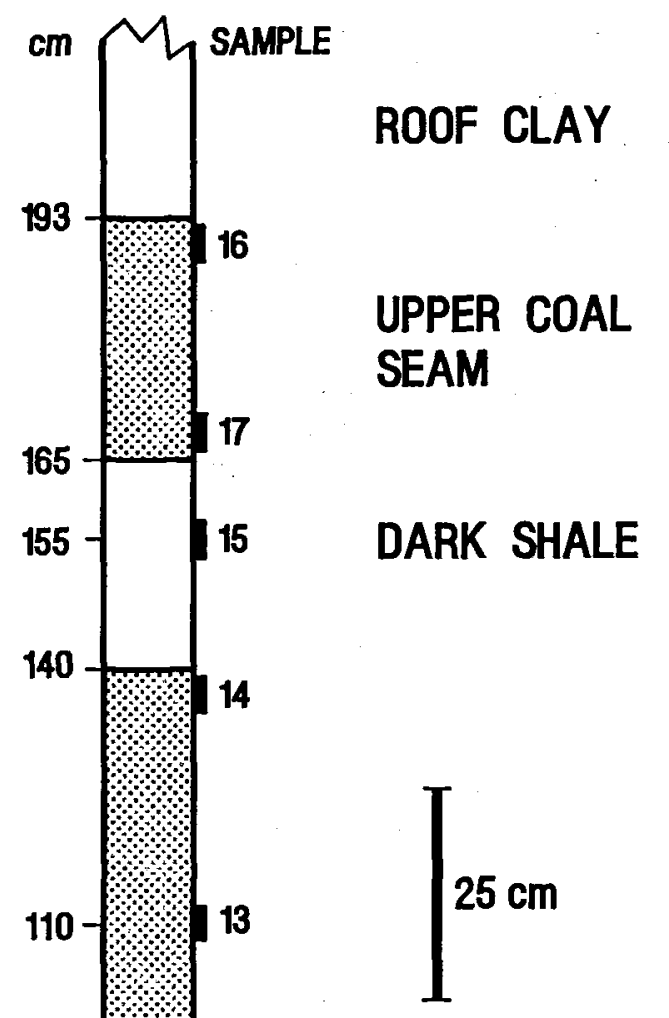

\section{LOWER COAL SEAM}

\section{UNDERCLAY}

Fig. 5. Locality A, profile with coal (shaded), clay (blank), and position of samples 08-17. locality A, where the profile shown on figs 4 and 5 was found at the end of a ca. $200 \mathrm{~m}$ long almost horizontal mineshaft. This was the only shaft still open in 1975 when the samples were collected. It is located close to profile 16 described by Rasmussen \& Noe-Nygaard (1969). The succession and thickness of strata in profile 16 equates to that of locality A shown in fig. 5 except that the lower coal band is only $60 \mathrm{~cm}$ thick in profile 16 and $140 \mathrm{~cm}$ thick on locality $\mathrm{A}$. The total thickness of coal at locality A (ca. $1.70 \mathrm{~m}$ ) is the largest known from the Faeroe Islands.

Locality B (fig. 3) is found in the bank of a small stream. The samples collected (03 and 05$)$ are coal and clay, but as the layers are dislocated, a sequence of strata cannot be recognized. A detailed lithostratigraphical correlation with the profile shown on fig. 5 from locality $A$ is therefore not possible.

Locality C (fig. 3) is located at the top of the coastal cliff. The single sample collected (29) consists of a mixture of coal and clay. It represents a stratigraphic level about $20 \mathrm{~m}$ below localities $A$ and $\mathbf{B}$.

\section{Sample preparation}

The preparation included treatment with cold hydrochloric acid $(\mathrm{HCl})$, and hot hydrofluoric acid (HF), followed by hot $\mathrm{HCl}$. Remaining minerals were removed by gravity separation in zinc chloride $\left(\mathrm{ZnCl}_{2}\right)$ solution with a specific gravity of 1.9. The preparation was sieved using a $10 \mu \mathrm{m}$ nylonfilter and inspected microscopically to determine further treatment. Sieving and microscopical inspection were employed between all the following preparation stages. With the exception of sample 08 , the samples employed for photographic documentation (plates 1-7) were treated with $5 \%$ potassium hydroxide $(\mathrm{KOH})$ solution. Plant fibres were removed with a $80 \mu \mathrm{m}$ or a $53 \mu \mathrm{m}$ nylon filter. Samples 09 and 11 to 14 were oxidated additionally with Schulze's solution for one minute and samples 10 and 16 for 0.5 minute. The oxidation was followed by $\mathrm{KOH}$ treatment (5\%, 2-5 minutes). Through this preparation, it was possible to obtain slides rich enough for counting palynomorphs (table 2). Glycerine was used as the embedding medium. 


\section{Systematic palynology}

Authors referred to above species level are omitted in the references.

Anteturma SPORITES H. Potonié

Turma TRILETES (Reinsch) Dettmann

Subturma AZONOTRILETES (Luber) Dettmann

Infraturma LAEVIGATI (Bennie \& Kidston) R. Potonié

\section{Deltoidospora Miner 1935}

Deltoidospora diaphana Wilson \& Webster 1946 Pl. 1, fig. A

Size: $26-(33)-38 \mu \mathrm{m} ; 5$ specimens.

Remarks: This species of Deltoidospora is characterized by its amb with rounded apices and faintly concave sides and the length of the laesurae, which are ca. 2/3 r.

Distribution: North America, Late Cretaceous (Stanley 1965; Norton \& Hall 1969) and Paleocene (Wilson \& Webster 1946; Stanley 1965).

Stereisporites Pflug 1953

Stereisporites sp.

Pl. 1, fig. B.

Size: $21-(22)-24 \mu \mathrm{m} ; 11$ specimens.

\section{cf. Stereisporites sp.}

Pl. 1, fig. C.

Size: $19 \mu \mathrm{m}$ (1 specimen only).

Remarks: Laesurae with undulating raised membraneous labra; contactarea more sculptured than rest of grain which is scabrate.

Undulatisporites Pflug 1953

Undulatisporites $\mathrm{sp}$.

Pl. 1, fig. D.

Size: $19-(20)-22 \mu \mathrm{m} ; 5$ specimens.

Remarks: No taxa compare closely with this species characterized by (a) long laesurae, $1 r$, with undulation raised labra, (b) triangular amb with straight to convex sides and faintly pointed to rounded apices, and (c) scabrate exine, less than $1 \mu \mathrm{m}$ thick.

Infraturma APICULATI (Bennie \& Kidston) R. Potonié

Baculatisporites Pflug \& Thomson 1953 Baculatisporites gemmatus Krutzsch 1959
Pl. 1, fig. E.

Size: $50-(53)-60 \mu \mathrm{m}$; size is unreliable as only 3 deformed specimens were measured.

Distribution: Paleogene of East Germany (Krutzsch 1959), France (Gorin 1974), and Spitsbergen (Manum 1962).

\section{Infraturma MURORNATI Potonié \& Kremp}

Trilites Cookson ex Couper 1953

Corrugatisporites Thomson \& Pflug 1953, Lygodioisporites Potonié ex Delcourt \& Sprumont 1955, and Trilitisporites Danzé-Corsin \& Laveine 1963 are considered junior synonyms of Trilites.

Trilites multivallatus (Pflug) Krutzsch 1959 P1. 2, figs A, B.

Size: $35-(62)-70 \mu \mathrm{m} ; 5$ specimens.

Remarks: This species is characterized by verrucae of varying size (max. diameter $5 \mu \mathrm{m}$, max. height $3 \mu \mathrm{m}$ ) which are often confluent to irregular rows which are spaced less than $2 \mu \mathrm{m}$ apart. This sculpture, which occurs all over the sporesurface, is stronger than in the related species $T$. solidus (Potonié) Krutzsch (1959, p. 150, pl. 27, figs 294-295), and $T$. paravallatus Krutzsch (1959, p. 152, pl. 27, fig. 298). In Thomson \& Pflug (1953, p. 55, pl. 2, figs 37-38) T. multivallatus was originally described as a subspecies of T. (al. Corrugatisporites) solidus Potonié and raised to species rank by Krutzsch (1959, p. 149). Distribution: Paleogene of Middle Europe (Thomson \& Pflug 1953), Paleocene, upper Landenian of Belgium (Roche 1973 for subfsp. magnus) and Oligocene and Miocene of East Germany (Krutzsch 1967).

\section{Subturma ZONOTRILETES Waltz}

Polypodiaceoisporites Potonié 1951 ex Potonié 1956

Polypodiaceoisporites marxheimensis (Mürriger \& Pflug ex Thomson \& Pflug) Krutzsch 1959

PI. 1, figs F, G.

Size: $50-(56)-60 \mu \mathrm{m} ; 13$ specimens.

Remarks: Presence of a cingulum $(4-6 \mu \mathrm{m}$ broad, at apices slightly thinner) distinguishes $P$. marxheimensis from Trilites multivallatus (pl. 2, figs A, B). Other published species of Polypodiaceoisporites are considerably smaller than $P$. marxheimensis.

Distribution: Late Paleocene of Belgium (Roche 
1969 \& 1973; Krutzsch \& Vanhoorne 1977), middle Eocene of Hungary (Kedves 1969) and Oligocene of East Germany (Krutzsch 1967). The oldest known occurrence is from the late Paleocene, upper Landenian of Belgium (al. $P$. macrospeciosus (Potonié) Kedves in Roche (1973, pl. 1, figs 5-7)).

\section{Turma MONOLETES Ibrahim}

Laevigatosporites Ibrahim 1933

Laevigatosporites haardtii (Potonié \& Venitz) Thomson \& Pflug 1953

Pl. 2, figs F, G.

Size: Length 26-(33)-40 $\mu \mathrm{m}$ (14 specimens), width 20-(24)-31 $\mu \mathrm{m}$ (13 specimens). Length/ width: $1.2-1.5$.

Distribution: Late Cretaceous to Paleocene of North America (Stanley 1965; Wilson 1978). Paleocene to Eocene of Spitsbergen (Manum 1962). Paleocene to Pliocene at numerous localities within Europe.

Laevigatosporites cf. haardtii (Potonié \& Venitz) Thomson \& Pflug 1953

Pl. 2, fig. $\mathrm{H}$.

Size: Length $28-(35)-46 \mu \mathrm{m}$ (9 specimens), width 18-(24)-30 $\mu \mathrm{m}$.Length/width: 1.2-1.7.

Remarks: With conspicuous folds.

\section{Reticuloidosporites Pflug 1953}

Reticuloidosporites dentatus Pflug 1953

Pl. 2, figs C, D, E.

Size: Length $42-(46)-52 \mu \mathrm{m}$ (16 specimens), width $26-(31)-35 \mu \mathrm{m}$ (15 specimens). Length/ width: $1.2-1.7$.

Remarks: "Reticulate" with low coni where the muri join.

Distribution: Late Cretaceous to early Tertiary of North America (e.g. Wilson 1978); middle Eocene of West Germany (Potonié 1956).

Anteturma POLLENITES R. Potonié

Turma SACCITES Erdtman

Subturma DISACCITES Cookson

Pityosporites Seward 1914 emend. Manum 1960 Pinuspollenites Raatz 1937 is in accordance with Manum (1960) and considered to be a junior synonym of Pityosporites. The species P. labdacus, $P$. alatus, and $P$. pacltovae are used according to descriptions in Krutzsch (1971).
Pityosporites labdacus (Potonié) Thomson \& Pflug 1953

Pityosporites cf. alatus (Potonié) Thomson \& Pflug 1953

Pityosporites cf. pacltovae Krutzsch 1971

?"cf. Pityosporites, Type A" Manum 1962

Pityosporites sp.

Piceaepollenites Potonié 1932

Piceaepollenites sp.

Size: Total width (including sacci) $60-(67)-70 \mu \mathrm{m}$ (5 specimens).

Cf. Piceaepollenites sp.

Turma ALETES Ibrahim

Sciadopityspollenites Raatz 1937 emend. Potonié 1958

Sciadopityspollenites serratus (Potonié \& Venitz) Raatz 1937

Pl. 6, figs $\mathrm{G}, \mathrm{H}$.

Size: $28-(29)-32 \mu \mathrm{m}$ (4 specimens).

Distribution: Paleogene of Spitsbergen (Manum 1962; Manum \& Throndsen 1986). Late Eocene to Pliocene of East Germany (Krutzsch 1971).

Inaperturopollenites Pflug \& Thomson 1953

Inaperturopollenites hiatus (Potonié) Thomson \& Pflug 1953

Pl. 6, figs $\mathrm{K}, \mathrm{L}$.

Size: $18-(24)-36 \mu \mathrm{m}$ (15 specimens).

Remarks: Smooth to microverrucate with a fissure, the length of which is at least half the diameter of the grain.

Distribution: Often mentioned in the literature from Late Cretaceous (Stanley 1965) to Pliocene (Meon-Vilain 1970). The oldest occurrence noted from Europe is late Paleocene of Belgium (Roche 1969, 1973).

Sequoiapollenites Thiergart 1938

Sequoiapollenites paleocenicus Stanley 1965

Pl. 6, figs I, J.

Size: $20-(24)-28 \mu \mathrm{m}$ (7 specimens).

Remarks: This species is characterized by a distinctive curvate ligula. The sculpture is scabrate but finer to absent on the ligula. $S$. papillapollenites (Rouse) Srivastava 1966 and $S$. polyformosus (Thiergart) Potonié 1958 differs from $S$. paleocenicus by having a shorter and straight ligula and by a finer sculpture which also covers the ligula.

Distribution: Late Cretaceous? (Plauchut \& Ja- 
Table 1. Characters used to distinguish types of Caryapollenites. Size and exine thickness in $\mu \mathrm{m}$.

\begin{tabular}{cllllll}
\hline $\begin{array}{l}\text { Caryapollenites } \\
\text { type no. }\end{array}$ & Size & $\begin{array}{l}\text { Exine } \\
\text { thickness }\end{array}$ & $\begin{array}{l}\text { Grains } \\
\text { measured }\end{array}$ & Shape, sides & Polar thinning & $\begin{array}{l}\text { Pores at } \\
\text { equator }\end{array}$ \\
\hline 1 & $34-(35)-37$ & $1-1.5$ & 4 & $\begin{array}{l}\text { slightly } \\
\text { convex } \\
\text { convex }\end{array}$ & diffuse & 0 \\
2 & $26-(27)-29$ & $1-1.5$ & 5 & $\begin{array}{l}\text { triangular } \\
\text { well defined }\end{array}$ & diffuse & 0 \\
3 & $32-(35)-37$ & ca. 1 & 7 & $\begin{array}{l}\text { strongly } \\
\text { convex } \\
\text { convex }\end{array}$ & $\begin{array}{l}\text { circular to } \\
\text { subtriangular } \\
\text { diffuse } \\
\text { often folded }\end{array}$ & $\begin{array}{l}\text { diffuse } \\
\text { strongly folded }\end{array}$ \\
\hline
\end{tabular}

tard 1976) to Paleocene (Stanley 1965; Srivastava 1972) of North America.

\section{Turma POROSES (Naumova) R. Potonié}

Momipites Wodehouse 1933 emend. Frederiksen \& Christopher 1978

Momipites amplus (Leffingwell) Nichols 1973

Pl. 3, figs A, B, C, D, E, ?F.

Size: $26-(30)-35 \mu \mathrm{m}$ (19 specimens).

Remarks: Distinguished from $M$. tenuipolus Anderson 1960 by large size and from $M$. anellus Nichols \& Ott 1978 by a more poorly defined area of normal exine thickness in the "polar" exine thinning. Pl. 3, fig. F is intermediate to Caryapollenites and it is possible that the arbitrary boundary between Caryapollenites (pores at one hemisphere) and Momipites (pores at equator) cuts through one population in the material studied.

Distribution: Paleocene Fort Union Formation of Wyoming, USA (Leffingwell 1971).

\section{Momipites coryloides Wodehouse 1933}

Pl. 3, figs $\mathbf{G}, \mathbf{H}$.

Size: $28-(30)-34 \mu \mathrm{m}$ (13 specimens).

Remarks: Distinguished from $M$. amplus (pl. 3. figs A-E) by the absence of an area of normal exine thickness in the polar exine thinning.

Distribution: North America, Paleocene and Eocene (Frederiksen \& Christopher 1978; Frederiksen 1979).

\section{Momipites sp. 1}

Pl. 3, fig. I.

Size: $30-(32)-37 \mu \mathrm{m}$ ( 3 specimens).

Remarks: Characterized by convex sides with a bend midway between the pores.

Caryapollenites Raatz ex Potonié 1960 emend. Krutzsch 1961

Subtriporopollenites Pflug \& Thomson in Thomson \& Pflug 1953 is similar to Caryapollenites, but differs by having a distinct columella layer or by having stronger sculpture.

Differences in shape (weakly concave to convex sides), position of pores (nearly equatorial to proximal), and absence or presence of proximal (ring) thinning led Nichols \& Ott (1978) to distinguish five species of Caryapollenites in the $\mathrm{Pa}$ leocene of the northwest USA. Additional forms of Caryapollenites are known from other American studies (Frederiksen \& Christopher 1978, e.g.). Some of these species might be junior synonyms of European species (e.g. C. wodehousei Nichols \& Ott 1978 might be a synonym of $C$. eogracilis Krutzsch \& Vanhoorne 1977). A comprehensive revision of American and European species of Caryapollenites would be relevant for this study. However, because early descriptions from Europe (e.g. Thomson \& Pflug 1953) are too cursory to allow sufficiant comparison without access to holotype material, a revision is not attempted.

Here the different forms of Caryapollenites are described in open nomenclature as types $1-6$, used for the stratigraphic discussion in the chap- 
ter "Evolutionary level of Momipites-Caryapollenites (Juglandaceae)".

Caryapollenites types 1-6.

Caryapollenites types $1-6$ have the following features in common: oblate triporate pollen with at least one pore located at the proximal hemisphere slightly off the equator, exine nearly smooth with a thin inner and thicker outer layer closely appressed without intermediate baculaelayer. The exine is thinned at the proximal pole. The pores consist of a smaller exopore and larger endopore, respectively $2-3$ and $8-10 \mu \mathrm{m}$ in size when seen from a polar direction. The shape is more or less triangular with convex sides and rounded apices. The characters used to distinguish the six types of Caryapollenites are shown on table 1.

Type 3 (Pl. 3, fig. L) with proximal pores resembles Caryapollenites veripites (Wilson \& Webster) Nichols \& Ott 1978 (Pocknall 1987, pl. 1, fig. 11).

Type 4 (Pl. 4, fig. A) with nearly equatorial pores resembles to Caryapollenites wodehousei Nichols \& Ott 1978 (Pocknall 1987, pl. 1, fig. 4).

Type 5 (Pl. 4, fig. B) with nearly equatorial pores, diffuse proximal thinning, and a single fold resembles Caryapollenites imparalis Nichols \& Ott 1978 as figured by Pocknall (1987, pl. 1, fig. 15). Cf. Caryapollenites type 6 (PI. 4, figs E, F) can be described as a Type 5 with folds. The folds give a superficial similarity to Platycaryapollenites Nagy, but Caryapollenites type 6 differs in having subequatorial, and not equatorial, pores and by lacking exine thinnings along the folds.

Type 1 (Pl. 3, fig. J) and type 2 (Pl. 3, fig. K) seem to be distinct, and possibly endemic forms.

\section{Trivestibulopollenites Pflug 1953}

Trivestibulopollenites betuloides Pflug 1953

PI, 4, figs C, D.

Size: $22-(25)-30 \mu \mathrm{m}$ (13 specimens).

Remarks: Probably interrelated with Triporates, Type E Manum (1962, p. 60, pl. 15, figs 18-21) described from the Paleocene Longyear-seam of Spitsbergen and with Paraalnipollenites confusus (Zaklinskaya) Hills \& Wallace 1969 which is characteristic in the Paleocene of Canada (Rouse 1977).

Distribution: Tertiary of West Germany (Pflug in
Thomson \& Pflug 1953), Oligocene of Hungary (Kedves 1974).

\author{
Alnipollentites Potonié 1931 \\ "Alnipollenites" trina (Stanley) Norton in Norton \\ \& Hall 1969 \\ Pl. 4, fig. G.
}

Size: $17-(18)-20 \mu \mathrm{m}$ ( 8 specimens).

Remarks: This species resembles Alnus pollen and the form genus Alnipollenites by having thickened ridges connecting the pores, but differs by having only three pores, each of which lack a vestibulum. This species was originally placed in Alnus (Stanley 1965) and transferred to Alnipollenites by Norton (in Norton \& Hall 1969). Because these specimens are triporate and non-vestibulate, the generic attribution is problematic and the genus is therefore placed in inverted commas.

Distribution: North America, early Paleocene (Stanley 1965; Norton \& Hall 1969), late Paleocene (Frederiksen 1979; Wilson 1978) and early Eocene (Frederiksen 1980).

\section{Alnipollenites verus Potonié 1931}

Pl. 4, fig. $\mathrm{H}$.

Size: $16-(22)-28 \mu \mathrm{m}$ (14 specimens).

Remarks: Alnus-like with 4-6 vestibulate pores connected by thickened ridges.

Distribution: Europe, late Paleocene (Roche $1969,1973)$ and younger. Known also from the Late Cretaceous (Wilson 1978) and Paleocene (Wilson 1978; Srivastava 1972; Elsik 1968) of North America.

\section{Alnipollenites sp.}

Pl. 4, fig. I.

Size: $20-(23)-26 \mu \mathrm{m}$ (10 specimens).

Remarks: With convex sides: $A$. verus differs from Alnipollenites sp. by having concave sides.

\section{Montanapollis Tschudy 1971}

Montanapollis sp.

Pl. 4, fig. J.

Size: equatorial width including pores $54 \mu \mathrm{m}$ (1 specimen).

Remarks: Only the figured specimen was found. M. globosiporus (Samoilovitch) Srivastava is known from the [Maastrichtian or] early Paleocene of Mull, Scotland (Srivastava 1975, Lund 
1983). It differs in having granulae/verrucae. Furthermore it is not spinose like the present Montanapollis specimen.

Turma PLICATES (Naumova) R. Potonié Subturma TRICOLPATES Van der Hammen \& Wymstra

Tricolpites Cookson ex Couper 1953 emend. Belsky, Boltenhagen \& Potonié 1965

Tricolpites hians Stanley 1965

Pl. 5, fig. A.

Size: $18-(22)-26 \mu \mathrm{m}$ (5 specimens).

Remarks: An oblate microreticulate species of Tricolpites with granulae at the margins of the colpi.

Distribution: North America, early Paleocene (Stanley 1965), late Paleocene (Elsik 1968), and Eocene (Potter 1976).

\section{Tricolpites parvus Stanley 1965}

Pl. 5, figs B, C.

Size: $15-(16)-20 \mu \mathrm{m}$ (8 specimens).

Remarks: The microreticulum is less distinct than by $T$. hians although the width of muri and diameter of luminae in both species are ca. $0.3 \mu \mathrm{m}$. Distribution: North America, Late Cretaceous to late Paleocene (Leffingwell 1971; Stanley 1965; Elsik 1968; Srivastava 1972).

Tricolpopollenites Pflug \& Thomson 1953

Tricolpopollenites sp. 1

Pl. 5, figs D, E, F.

Size: equatorial diameter $13-(17)-21 \mu \mathrm{m}$ (5 specimens), length $21-(23)-24 \mu \mathrm{m}$ (3 specimens).

Remarks: This species is characterized by its small size and sculpture consisting of closely packed baculae which are less than $0.5 \mu \mathrm{m}$ height. In resembles $T$. papillotegillatus Trevisan from the late Miocene of Italy (Trevisan 1967).

\section{Tricolpopollenites sp. 2}

P1. 5, fig. G.

Size: equatorial diameter $20-(21)-23 \mu \mathrm{m}$ ( 7 specimens), length 22-(25)-27 $\mu \mathrm{m}$ ( 7 specimens).

Remarks: Characterized by a fine meshed reticulum (luminae diameter and height of muri less than $0.5 \mu \mathrm{m}$ ).

Tricolpopollenites sp. 3

Pl. 5, figs $\mathrm{H}$, I.
Size: equatorial diameter $22-(23)-25 \mu \mathrm{m}$ (4 specimens), length 28-(30)-34 $\mu \mathrm{m}$ (4 specimens).

Remarks: Distinguished by a relatively rough reticulum (lumina diameter nearly $1 \mu \mathrm{m}$, muri width and height $0.5 \mu \mathrm{m}$ ).

Pocknall (1987, pl. 1, fig. 8) figured a specimen similar to $T$. sp. 3 as Tricolpites sp. A.

Subturma TRICOLPORATES Van der Hammen \& Wymstra

Tricolporopollenites Pflug \& Thomson 1953

Tricolporopollenites baculoferus Pflug 1953

Pl. 5, figs J, K.

Size: equatorial diameter 14-(19)-28 $\mu \mathrm{m}$ (15 specimens), length 17-(23)-32 $\mu \mathrm{m}$ (13 specimens).

Remarks: Fraxinoipollenites variabilis Stanley (1965, p. 306, pl. 45, figs 33-34) is a junior synonym of $T$. baculoferus Pflug (in Thomson \& Pflug, 1953, p. 105, pl. 14, figs 4-8) which has also been assigned to Favitricolporites Sah 1967 (Srivastava 1972). The pores are poorly developed and in many specimens no pores were observed. The tips of the baculae (nearly $1 \mu \mathrm{m}$ long) and clavae are united in a tectum which is microreticulate with a lumina diameter of ca. $0.5 \mu \mathrm{m}$. Presence of the clavae distinguishes $T$. baculoferus from $T$. retiformis Pflug \& Thomson (in Thomson \& Pflug 1953).

Distribution: Europe, early Tertiary (Thomson \& Pflug 1953), North America, early Paleocene to middle Eocene (Rouse \& Srivastava 1972; Tschudy 1973 e.g.).

Tricolporopollenites villensis (Thomson) Thomson \& Pflug 1953

Pl. 5, fig. L.

Size: equatorial diameter $14-(15)-17 \mu \mathrm{m}$ (3 specimens), length 18-(19)-19 $\mu \mathrm{m}$ (3 specimens).

Distribution: Europe, early Eocene (Kedves 1969) to Miocene (Gorin 1974).

Tricolporopollenites sp.

Pl. 6, figs A, B.

Size: equatorial diameter 15-(18)-21 $\mu \mathrm{m}$ (15 specimens), length 22-(25)-26 $\mu \mathrm{m}$ (14 specimens).

Remarks: The thin (ca. $0.5 \mu \mathrm{m}$ ) exine and the sculpture of closely spaced narrow striae (width and height ca. $0.3 \mu \mathrm{m}$ ) without descernible col- 
Table 2. Percentages of pollen and spore taxa from localities A (samples 09-14), B (sample 05), and the stratigraphically deeper locality C (sample 29), “+” denotes very rare taxa observed outside the count of 200 specimens per sample.

\begin{tabular}{|c|c|c|c|c|c|c|c|c|c|}
\hline \multirow[t]{2}{*}{ Palynomorph taxa } & \multicolumn{9}{|c|}{ Samples } \\
\hline & 29 & 09 & 10 & & 11 & 12 & 13 & 14 & 05 \\
\hline Deltoidospora diaphana & + & & 5.0 & & 2.5 & 3.0 & 1.5 & 2.0 & 10.5 \\
\hline $\begin{array}{l}\text { Stereisporites } \mathrm{sp} . \\
\text { cf. Stereisporites } \mathrm{sp} \text {. }\end{array}$ & & & & & & 3.5 & 16.5 & 2.5 & $\begin{array}{c}3.5 \\
+\end{array}$ \\
\hline Undulatisporites sp. & & & 0.5 & & 4.0 & 2.5 & 3.5 & & 1.0 \\
\hline Baculatisporites gemmatus & & & & & 4.0 & & 5.5 & 2.5 & \\
\hline Trilites multivallatus & & & 1.5 & & & & & & \\
\hline Polypodiaceoisporites marxheimensis & & & 15.0 & & & & & & \\
\hline Laevigatosporites haardtii & 2.0 & 6.5 & 8.0 & & 6.0 & 4.0 & 1.5 & 2.0 & 20.0 \\
\hline Laevigatosporites cf. haardtii & 0.5 & 1.5 & + & & & & & & 6.5 \\
\hline Reticuloidosporites dentatus & & & & & & & & 5.0 & 11.5 \\
\hline Pityosporites labdacus & 0.5 & + & + & & 1.5 & & 1.5 & 0.5 & 1.0 \\
\hline Pityosporites cf. alatus & & & + & & & + & & & \\
\hline Pityosporites cf. pacltovae & & & & & + & 2.5 & & & \\
\hline ?"cf. Pityosporites Type A" Manum & 1.0 & 1.0 & 0.5 & & 1.0 & & & + & 2.5 \\
\hline Pityosporites sp. & + & 2.0 & & & & & & & \\
\hline Piceaepollenites sp. & 1.5 & 1.0 & 1.0 & & 2.5 & & 3.0 & 3.5 & 3.5 \\
\hline Sciadopityspollenites serratus & & & & & & & & & + \\
\hline Inaperturopollenites hiatus & 25.5 & 38.0 & 30.5 & & 29.0 & 42.5 & 31.5 & 47.5 & 11.0 \\
\hline Sequoiapollenites paleocenicus & 0.5 & 3.0 & 1.0 & & 3.5 & 4.0 & 5.0 & 12.0 & \\
\hline Momipites amplus & 22.5 & 10.5 & 10.0 & • & 16.0 & 18.0 & 19.0 & 8.0 & 22.5 \\
\hline Momipites coryloides & & 1.0 & 4.0 & & 1.0 & 4.0 & + & 0.5 & + \\
\hline Momipites sp. 1 & & & + & & 1.0 & 2.0 & & & \\
\hline Caryapollenites type 1 & 0.5 & 0.5 & & & 0.5 & & & & \\
\hline Caryapollenites type 2 & 2.0 & 2.0 & & & 1.0 & & & & \\
\hline Caryapollenites type 3 & 7.5 & 1.5 & & & 1.0 & & 2.5 & & \\
\hline Caryapollenites type 4 & 12.0 & & & & 1.0 & 2.5 & & & \\
\hline Caryapollenites type 5 & 9.5 & 1.0 & & & 2.5 & 2.5 & & & + \\
\hline cf. Caryapollenites type 6 & & + & + & & & & 3.5 & & + \\
\hline Trivestibulopollenites betuloides & 0.5 & 1.0 & & & & & 5.5 & 2.5 & 5.5 \\
\hline "Alnipollenites" trina & & 2.5 & 3.5 & & 1.5 & & & & \\
\hline Alnipollenites verus & 1.0 & 5.5 & 4.5 & & 8.0 & & & & + \\
\hline Alnipollenites sp. & + & 3.0 & 5.5 & . & 4.5 & 2.5 & & & \\
\hline Montanapollis sp. & 0.5 & & & & & & & & \\
\hline Tricolpites hians & & 2.5 & & & & & & & \\
\hline Tricolpites parvus & + & & & & & & & 9.5 & 1.0 \\
\hline Tricolpopollenites sp. 1 & & 11.5 & 2.5 & & 6.5 & 6.5 & & & \\
\hline Tricolpopollenites sp. 2 & & 2.5 & 1.0 & & 1.5 & & & & \\
\hline Tricolpopollenites sp. 3 & & & & & & & & 2.0 & \\
\hline Tricolporopollenites baculoferus & 6.5 & & & & & & & & \\
\hline Tricolporopollenites villensis & & 1.5 & & & & & & & \\
\hline Tricolporopollenites sp. & 6.5 & & & & & & & & \\
\hline Phaseoliidites stanleyi & & & 6.0 & & & & & & \\
\hline Cupanieidites sp. & & 0.5 & & & & & & & \\
\hline Pesavis tagluensis & + & + & & & & & & & \\
\hline Other fungal spores (not counted) & + & + & & & & + & + & + & .. \\
\hline Number of species & 23 & $\therefore 26$ & 22 & & 23 & 15 & 14 & 15 & 19 \\
\hline
\end{tabular}

umella layer separate this species from similar published species like T. striatensis Krutzsch \& Vanhoorne 1977 and T. striatoides Krutzsch 1961. "Aesculiidites" A (Rouse 1977, pl. 2, fig. 25) is very similar but appears to have a slightly thicker wall and a more rhombic outline, according to the single photo provided by Rouse (1.c.).

Phaseoliidites Elsik 1968

\section{Phaseoliidites stanleyi Elsik 1968}

Pl. 6, figs E, F.

Size: $18-(22)-24 \mu \mathrm{m}$ (13 specimens).

Remarks: This tricolporate pollen is distinguished by verrucae arranged in belts bounding the colpi. These belts are confluent near the poles giving the pollen a syncolpate appearance. Distribution: North America, Paleocene (Elsik 1968). 
Cupanieidites Cookson \& Pike 1954 emend. Chmura 1973

Cupanieidites sp.

Pl. 6, figs C, D.

Size: $21 \mu \mathrm{m}$ (one specimen).

Fungi

Fungal spores occur in most samples. Only one morphologically characteristic and stratigraphically restricted type is determined to the speciesrank. Other spores could not be determined to species and are tentatively assigned to genera only; Multicellaesporites Elsik 1968 emend. Sheffy \& Dilcher 1971 and Brachysporisporites Lange \& Schmidt 1971 shown on pl. 7.

Pesavis Elsik \& Jansonius 1974

Pesavis tagluensis Elsik \& Jansonius 1974

P1. 7, fig. D.

Size: $34-35 \times 38-40 \mu \mathrm{m}$ ( 3 specimens).

This characteristic species is well known from the "middle" Paleocene and Eocene of Canada (e.g. Rouse 1978).

Algae

Sigmopollis Hedlund 1965

Sigmopollis sp.

Pl. 7, figs $\mathrm{K}, \mathrm{L}, \mathrm{M}$.

Similar microfossils with an S-shaped furrow and spines over the surface are known from Quaternary eutrophic to mesotrophic lake sediments (Van Geel, Hallewas \& Pals 1983, p. 312, pl. 1, type 128).

\section{Paleoenvironment}

The absence of marine palynomorphs indicates a non-marine paleoenvironment. Presence of the fresh water algae Sigmopollis suggests a eutrophic to mesotrophic lake environment (Van Geel et al. 1983) in sample 10 (table 2) from the lower main coal seam at locality A. It is probable that this portion of the coal seam was deposited under lacustrine conditions. An acme of fern spores including frequent Polypodiaceoisporites marxheimensis (table 2) indicates that this lake was surrounded by swamp vegetation well represented by ferns or that the lake was fed by streams from such fern rich areas.

As seen in table 2, there is a change within the coal from a species rich vegetation with "Alnus"
(Alnipollenites verus in sample 9-11) to one poorer in species and characterized by "Sphagnum" (Stereisporites sp.). This probably reflects a change to more oligotrophic conditions as nutrients were regionally leached from the volcanic soil.

The deposition of the coal and the presence of polypodiaceous ferns suggests a humid climate. Palm pollen like Proxapertites Van der Hammen and Spinizonopollenites Muller, which were widely distributed in the tropics during the Paleocene and Eocene (Germeraad, Hopping \& Muller 1968; Muller, de Di Giacomo \& Van Erve 1987), are absent. This precludes a tropical affinity of the flora. Caryapollenites generally exceeds $5 \%$ of the pollen count. In the present day North America such values of Carya pollen occur from $25^{\circ}-45^{\circ} \mathrm{N}$ (Delcourt, Delcourt \& Webb 1984, fig. 37). Pollen of Cupressaceae and Taxodiaceae (Inaperturopollenites hiatus and Sequoiapollenites paleocenicus) generally amount to more then $30 \%$ of the pollen count. At present such values occur south of $35^{\circ} \mathrm{N}$ in USA (Delcourt et al. 1984, fig. 29).

Considering these percentages and the minor quantity of bisaccate pollen (table 2 and Delcourt et al. 1984, fig. 13, e.g.) the best fit of the Faeroe Islands coal pollen flora is with pollen spectra known from NE Mississippi, USA. This suggests that the climate during the deposition of the Faeroe Islands coals was warm temperate. This is supported by the observation of brownish weathering (soil colours) between the lavas of the lower basalt series (Waagstein et al. 1984).

\section{Palynostratigraphy}

A. Correlation by concurrent range of species.

Compared with Europe, the presence of Trilites multivallatus, Polypodiaceoisporites marxheimensis and Caryapollentites clearly indicate a (late) late Paleocene (late Landenian) or younger age. An early Paleocene age is precluded. Compared with North America, the species Deltoidospora diaphana, Sequoiapollenites paleocenicus, Tricolpites parvus, Tricolpopollenites sp.'3 (Tricolpites sp. A Pocknall 1987), and Phaseoliidites stanleyi suggest an age not younger than the Paleocene. The problem with the first four species is their morphological simplicity; they might have been 
ignored in some studies. Phaseoliidites stanleyi is morphologically peculiar and was described from the late Paleocene of Texas; however, it has been recorded in one study only and cannot be utilized with full confidence as a late Paleocene marker. As a result, an Eocene age cannot be completely excluded, but considering the known concurrent ranges, a (late) late Paleocene age is most probable.

\section{B. "Eocene" dating by Laufeld 1965.}

In 1965, when the Faeroe Islands sequence was considered to be of Eocene-Oligocene age (Rasmussen 1963), S. Laufeld published the results of a preliminary palynological investigation of the Faeroe Islands coals. He noted: "The percentual composition of the flora combined with the known stratigraphic range of certain types, makes it, however, reasonable to look upon it as Eocene" (Laufeld 1965, p. 236-237). Laufeld did not elaborate, but from the description of the microflora it appears to be the low percentage, less than 1 percent, of "two-winged coniferous pollen" and the presence of "monocolpate pollen grains with affinities to those of Recent palms". These data indicate a pre-Oligocene age; however, they cannot be used to differentiate the Eocene from the Paleocene.

\section{Correlation with Krutzsch's Zone 10.}

The composition of the microflora (table 2) with common Caryapollenites and the absence of Normapolles corresponds to Krutzsch's Zone $\mathbf{1 0} \mathrm{mi}$ croflora, which is of late Paleocene age in its type area. This zone was established on pollen and spore microfloras from Central Europe and suggests a cooler climate than that of the over- and underlying zones with Normapolles (Krutzsch 1966). Dating the Faeroe Islands microflora by correlation with Krutzsch's Zone 10 microflora seems problematic, as (a) the Faeroe microflora is isolated and not intercalated between warmer microfloras with Normapolles and (b) climatically controlled zonal boundaries might differ in age from Central Europe to the Faeroe Islands.

No sequence with a maximum of Caryapollenites / minimum of Normapolles intercalated between Normapolles floras has been reported north of Central Europe. However, specimens of the Normapolles group were found in the early Paleocene of Spitsbergen (Manum 1962; Manum \& Throndsen 1986) and in the middle to late Eocene of D.S.D.P. Leg 38 Site 346 near Jan Mayen in the Norwegian Sea (Koreneva, Zaklinskaya \& Bratseva 1976). These northern microfloras with Normapolles are respectively older and younger than the Faeroe microflora as dated here under the headings "Correlation by concurrent range of species" and "Evolutionary level of Momipites-Caryapollenites (Juglandaceae)". It is therefore suggested that a complete succession of microfloras in the Faeroe area comprise Normapolles microfloras below and above the Caryapollenites microflora actually observed. This hypothetical succession compares well with the succession described from Central Europe where the Caryapollenites maximum corresponds to Zone 10 (Krutzsch 1966). The Faeroe Caryapollenites microflora is therefore correlated with Zone 10 of Krutzsch (l.c.).

In central Europe, Zone 10 is not located at the top of the Paleocene as considered by Krutzsch (1966); it contains several species of the dinoflagellate cyst "Eisenackia" (Krutzsch 1.c.) indicating that it corresponds to the informal margarita dinoflagellate Zone of Knox, Morton \& Harland (1981), which is early late Paleocene in age. Moreover it is followed by Zone 11 established from Landenian strata in Belgium now placed in the youngest Paleocene (Schumacker-Lambry 1978 and introduction here).

In the northern North Sea, a Caryapollenites rich microflora was noted by Malm, Christensen, Furnes, Løvlie, Ruselåtten \& Østby (1984). This assemblage was associated with late late Paleocene dinoflagellate cysts typical of the Deflandrea oebisfeldensis acme zone sensu Knox et al. (1981). Compared with the margarita Zone age of Zone 10 in Central Europe, this demonstrates that the top of Zone 10 / Caryapollenites rich microfloras is diachronous within the late Paleocene and becomes younger to the north.

The composition of the Faeroe coal microflora with its common Caryapollenites and absence of Normapolles (Zone 10 of Krutzsch) suggests a late Paleocene age. As the top of this microflora is diachronous becoming younger to the north, it might range into the earliest Eocene in the Faeroe Islands. 
D. Evolutionary level of MomipitesCaryapollenites (Juglandaceae).

Caryapollenites and the related genus Momipites - both similar to pollen of the modern family Juglandaceae - are conspicuous elements of the Faeroe Islands assemblage (table 2, pls 3, 4). In this respect, the Faeroe Islands assemblage resembles those of the Paleocene of the northern Western Interior of the USA (Pocknall 1987, e.g.).

Based on subtle morphologic variations within Momipites and Caryapollenites, Nichols \& Ott (1978) defined twelve species and used these to subdivide the Paleocene section in the Wind River Basin of Wyoming into six zones, P1-P6 numbered in ascending order. Caryapollenites is absent in $\mathrm{P} 1$ and $\mathrm{P} 2$. At the $\mathrm{P} 2 / \mathrm{P} 3$ junction $\mathrm{Ca}$ ryapollenites develops from Momipites by a slight shift in proximal direction of the three pores. This trend continues strategraphically upwards so that forms with pores not touching the amb becomes established in zone P5. At the junction between P6 and the overlying Eocene zone E "Platycarya", another representation of Juglandaceae-like pollen appears. All Caryapollenites species occur up to P6. Whether they occur in the Eocene is not clearly stated by Nichols \& Ott (1978).

Above zone P4 the stratigraphic utility of this shift in pore orientation was confirmed in a study by Pocknall (1987) which investigated the upper Paleocene and lower Eocene of the Powder River Basin of Wyoming and Montana. Text-figure 3 in Pocknall (1987) is useful for correlation of the Faeroe Islands microflora. This figure shows overlap of ranges of Caryapollenites species with nearly equatorial pores ( $C$. wodehousei / $C$. type 4 here) and species with proximal pores $(C$. inelegans, $C$. veripites / $C$. type 3 here) within a section in the Paleocene Port Union Formation. This section and the overlying part of the Fort Union Formation contain Tricolpites sp. A Pocknall (Tricolpopollenites sp. 3 here), which is absent in the overlying Eocene portion of the Wasatch Formation. This younger unit is characterized palynologically by the presence of "Platycarya", which is absent in the Faeroe Islands coals.

These data indicate a correlation of the Faeroe Islands coals with the upper Paleocene portion of the Fort Union Formation in the northern Western Interior of the USA.

\section{Combination of magneto- and palynostratigraphy}

The magnetostratigraphic correlation of the basalt sequence herein proposed indicates that the coals investigated occupy a position near the boundary between polarity chrons $24 \mathrm{r}$ and 25 . This corresponds to a late late Paleocene age (fig. 2).

The "correlation by concurrent range of species" and the "evolutionary level of MomipitesCaryapollenites (Juglandaceae)" also indicate a late Paleocene age. There is no palynological evidence for an Eocene age.

So a late Paleocene age is given to these coals of the Faeroe Islands, and palynological and magnetostratigraphic datings both support this conclusion.

Acknowledgements. This paper is based on a M.Sc. thesis at the Geological Institute, University of Aarhus, Denmark, carried out under the supervision of $\mathrm{K}$. Raunsgaard Pedersen. B. Larsen assembled the photographic plates. R. E. Dunay, Mobil, London, kindly improved the English manuscript.

The government of the Faeroe Islands provided financial support for the field work.

\section{Dansk sammendrag}

Mikrofloraen i kul indlejret mellem basaltbænke på Færøerne er kendetegnet af høj hyppighed af Momipites-Caryapollenites, lav hyppighed af bisaccate pollen og fravær af Normapolles gruppen. Arter som Phaseoliidites stanleyi og Pesavis tagluensis giver mikrofloraen større lighed med nordamerikanske end med europæiske mikrofloraer. På grundlag af overlapningen af kendte rækkevidder af de fundne arter og på grundlag af udviklingsniveauet $i$ familien Juglandaceae samt mikrofloraens kvantitative sammensætning bestemmes den sandsynlige alder som yngre Paleocæn. Denne alder er i overensstemmelse med en ny paleomagnetisk korrelation som foreslås her. Klimaet var humidt og varmt tempereret. Kullaget mellem den nederste og mellemste basalt serie blev delvis aflejret $i$ en sø. Aftagende hyppighed af Alnus-lignende pollen og tiltagende hyppighed af Sphagnum-lignende sporer opad i 
kullaget synes at vise en aftagende mængde næringssalte som følge af fremskridende regional udvaskning.

\section{References}

Abrahamsen, N. 1967: Some paleomagnetic investigations in the Faeroe Islands. Bull geol. Soc. Denmark, 17, 371-384.

Anderson, R. Y. 1960: Cretaceous-Tertiary palynology eastern side of the San Juan Basin, New Mexico. New Mexico Bur. Mines and Mineral Resources, Mem., 6, $59 \mathrm{pp}$.

Berggren, W. A., Kent, D. V. \& Flynn, J. J. 1985: Jurassic to Paleogene: Part 2. Paleogene geochronology and chronostratigraphy. In Snelling, N. J. (Ed.); The Chronology of the Geological Record. The Geological Society Memoir, 10, 141-195, Blackwell.

Bott, M. H. P., Saxov, S., Talwani, M. \& Thiede, J. 1983: Structure and Development of the Greenland-Scotland Ridge, NATO Conference Series, IV, 8, 685 pp.

Curry, D., Adams, C. G., Boulter, M. C., Dilley, F. C., Eames, F. E., Funnell, B. M. \& Wells, M. K. 1978: A correlation of Tertiary rocks in the British Isles. Geol. Soc. Lond., Special Report, 12, $72 \mathrm{pp}$.

Delcourt, P. A., Delcourt, H. R. \& Webb, T. III 1984: Atlas of mapped distributions of dominance and modern pollen percentages for important tree taxa of eastern North America. AASP Contribution Series 14, $131 \mathrm{pp}$.

Elsik, W. C. 1968: Palynology of a Paleocene Rockdale lignite, Milam County, Texas. II. Morphology and taxonomy (end.) Pollen Spores 10 (3), 599-664.

Elsik, W. C. \& Jansonius, J. 1974: New genera of Paleogene fungal spores. Can. Jour. Bot., 52, 953-958.

Frederiksen, N. O. 1979: Paleogene sporomorph biostratigraphy, Northeastern Virginia. Palynology 3, 129-167.

Frederiksen, N. O. 1980: Paleogene Sporomorphs from South Carolina and Quantitative Correlations with the Gulf Coast. Palynology 4, 125-179.

Frederiksen, N. O. \& Christopher, R. A. 1978: Taxonomy and biostratigraphy of Late Cretaceous and Paleocene triatriate pollen from South Carolina. Palynology 2, 113-145.

Germeraad, J. H., Hopping, C. A. \& Muller, J. 1968: Palynology of Tertiary sediments from tropical areas. Rev. Palaeobotan. Palynol., 6, 189-348.

Gorin, G. 1974: Etude palynostratigraphique des sédiments Paléogènes de la Grande Limagne (Massif central; France). Univ. Geneve, $314 \mathrm{pp}$.

Harland, W. B., Cox, A. V., Llewellyn, P. G., Pickton, C. A. G., Smith, A. G. \& Walters, R. 1982: A geologic time scale. Cambridge Earth Science Series, $131 \mathrm{pp}$.

Hills, L. V. \& Wallace, S. 1969: Paraalnipollenites, a new form genus from uppermost Cretaceous and Paleocene rocks of arctic Canada and Russia. Contributions to Canadian Paleontology. Bull Geol Surv Canada. 182. 139-145.

Kedves, M. 1969: Palynological studies on Hungarian early Tertiary deposits. Acad. Kiado, Budapest, 84 pp.

Kedves, M. 1974: Paleogene fossil sporomorphs of the Bakony Mountains. Part II. Stud. Biol. Hungarica 13, 7-124.

Knox, R. W. O'B., Morton, A. C. \& Harland, R. 1981: Stratigraphical Relationships of Palaeocene Sands in the UK Sektor of the Central North Sea. In Illing, L. V. \& Hobson, G. D. (eds.), Petroleum Geology of the Continental Shelf of North-West Europe, 267-281.

Koreneva, E. V., Zaklinskaya, E. D. \& Bratseva, G. M. 1976: Palynology studies of sites 336, 338, 345, 346 and 348. Initial Rep. DSDP leg. 38, 1169-1193.
Krutzsch, W. 1959: Mikropalăontologische (sporenpalāontologische) Untersuchungen in der Braunkohle des Geiseltales, I. Geologie 8 (21-22), 425 pp.

Krutzsch, W. 1961: Beitrag zur Sporenpalăontologie der präoberoligozänen kontinentalen und marinen Tertiärablagerungen Brandenburgs. Ber. geol. Ges. DDR, 5 (4), 290 343.

Krutzsch, W. 1966: Die sporenstratigraphische Gliederung des älteren Tertiär im nördlichen Mitteleuropa (Paläozān-Mitteloligozän). Methodische Grundlagen und gegenwärtiger Stand der Untersuchungen. Abh. zentr. geol. Inst. 8, 112149.

Krutzsch, W. 1967: Der Florenwechsel im Alttertiär Mitteleuropas auf Grund von sporenpaläontologischen Untersuchungen. Abh. zentr. geol. Inst. 10, 17-37.

Krutzsch, W. 1971: Atlas der mittel- und jungtertiären dispersen Sporen - und Pollen sowie der Mikroplanktonformen des nördlichen Mitteleuropas. VI. Coniferenpollen (Saccites und "Inaperturates"). VEB Deutscher Verlag der Wissenschaften, Berlin, 234 pp.

Krutzsch, W. \& Vanhoorne, R. 1977: Die Pollenflora von Epinois und Loksbergen in Belgien. Palaeontographica $B$. $163(1-4), 1-110$.

Laufeld, S. 1965: Sporomorphs in Tertiary coal from the Faeroe Islands. Geol. Fören, Stockholm Förhandl., 87, 231-238.

Leffingwell, H. A. 1971: Palynology of the Lance (Late Cretaceous) and Fort Union (Paleocene) Formations of the Type Lance Area, Wyoming, Geol. Soc. America Spec. Paper $127,1-64$.

Lund, J. 1981: Eine ober-paläozäne Mikroflora von den Färöern, Dänemark. Cour. Forsch.-Inst. Senckenberg, 50, 41-45.

Lund, J. 1983: Biostratigraphy of interbasaltic coals from the Faeroe Islands. In Bott, M. H. P., Saxov, S., Talwani, M. \& Thiede, J. (Eds.), Structure and Development of the Greenland-Scotland Ridge, 417-423, Plenum.

Malm, O. A., Christensen, O. B., Furnes, H., Løvlie, R., Ruselătten, H. \& Østby, K. L. 1984: The Lower Tertiary Balder Formation: An organogenic and tuffaceous deposit in the North Sea region. In Spencer, A. M. (ed.), Petroleum Geology of the North European Margin, Norwegian Petroleum Society, 149-170.

Manum, S. B. 1960: On the genus Pityosporites Seward 1914. With a new description of Pityosporites antarcticus Seward. Nytt. Mag. Bot. 8, 11-15.

Manum, S. B. 1962: Studies in the Tertiary flora of Spitsbergen, with notes on Tertiary floras of Ellesmere Island, Greenland, and Iceland. Norsk Polarinst. 125, $127 \mathrm{pp}$.

Manum, S. B. \& Throndsen, T. 1986: Age of Tertiary formations on Spitsbergen. Polar Research 4 n.s., 103-131.

Meon-Vilain, H. 1970: Palynologie des formations Miocenes Superieures et Pliocenes du Bassin du Rhone (France). Docum. Lab. Géol. Fac. Sci. Lyon 38, 1-167.

Muller, J., de Di Giacomo, E. \& van Erve, A. W. 1987: A palynological zonation for the Cretaceous, Tertiary, and Quaternary of northern South America. American Association of Stratigraphic Palynologists, Contributions Series, 19, 7-76.

Nichols, D. J. 1973: North American and European species of Momipites ("Engelhardtia") and related genera. Geoscience and Man, 7, 103-117.

Nichols, D. J. \& Ott, H. L. 1978: Biostratigraphy and evolution of the Momipites-Caryapollenites lineage in the Early Tertiary in the Wind River Basin, Wyoming. Palynology 2, 93-112.

Norton, N. J. \& Hall, J. W. 1969: Palynology of the Upper Cretaceous and Lower Tertiary in the type locality of the Hell Creek Formation, Montana, USA. Palaeontographica B 125 (1-3), 1-64.

Pflug, H. D. 1953: Zur Entstehung und Entwicklung des An- 
giospermiden Pollens in der Erdgeschichte. Palaeontographica $B$ 95 (4-6), 60-171.

Plauchut, B. P. \& Jutard, G. G. 1976: Cretaceous and Tertiary stratigraphy, Banks and Eglinton Islands and Anderson Plain (N. W. T.). Bull. Canad. Petrol. Geol. 24 (3), 321371.

Pocknall, D. T. 1987: Palynomorph biozones for the Fort Union and Wasatch Formations (Upper Paleocene Lower Eocene), Powder River Basin, Wyoming and Montana, U.S.A. Palynology 11, 23-35.

Potonié, R. 1956: Synopsis der Gattungen der Sporae dispersae. I. Teil: Sporites. Beih. Geol. Jb. 23, 103 pp.

Potonie, R. 1958: Synopsis der Gattungen der Sporae dispersae. II. Teil: Sporites (Nachträge), Saccites, Aletes, Praecolpates, Polyplicates, Monocolpates. Beih. Geol. Jb. $31,114 \mathrm{pp}$.

Potter, F. W. Jr. 1976: Investigations of angiosperms from the Eocene of southeastern North America: Pollen assemblages from Miller Pit, Henry County, Tennessee. Palaeontographica $B 157$ (1-4), 44-96.

Raatz, G. V. 1937: Mikrobotanisch-stratigraphische Untersuchung der Braunkohle des Muskauer Bogens. Abh. Preussischen geol. Landesanstalt, Neue Folge 183, 48 pp.

Rasmussen, J. \& Noe-Nygaard, A. 1969: Beskrivelse til Geologisk Kort over Farøerne. Danmarks geol. Unders. I. Rk. $24,370 \mathrm{pp}$.

Roche, E. 1969: Étude palynologique de sédiments du Montien continental et du Landenien Supérieur en Hainaut. Bull. Soc. belge Géol., Paléont., hydrol. 78 (2), 131-146.

Roche, E. 1973: Marqueurs stratigraphiques (pollen et spores) du Paléocène et de l'Eocène inférieur de Belgique. Acad. R. belg. Bull. Cl. Scient. 59 (9), 956-969.

Rouse, G. E. 1977: Paleogene palynomorph ranges in Western and Northern Canada. Amer. Ass. Strat. Palynol. Contri. Ser. 5A, 48-65.

Rouse, G. E. \& Srivastava, S. K. 1972: Palynological Zonation of Cretaceous and Early Tertiary Rocks of the Bonnet Plume Formation, Northeastern Yukon, Canada. Canadian Jour. Earth Sci. 9 (9), 1163-1179.

Schumacker-Lambry, J. 1978: Palynologie du Landenien inférieur (Paléocène) à Gelinden-Overbroek/Belgique. Relations entre les microfossiles et le sédiment. Lab. Paléobot. Palynol. (éd.), Univ. Liège, $157 \mathrm{pp}$.

Springhorn, R. 1984: Faunistische Übereinstimmung zwischen Nordamerika und Europa im Untereozän sowie biostratigraphische und paläomagnetische Korrelation der Ostgrönland-Faeroer-Basalte. $N$. Jb. Geol. Paläont. Mh., H. $4,248-256$.

Srivastava, S. K. 1966: Upper Cretaceous microflora (Maestrichtian) from Scollard, Alberta, Canada, Pollen Spores, 8 (3), 497-552.
Srivastava, S. K. 1972: Some spores and pollen from the Paleocene Oak Hill Member of the Naheola Formation. Alabama (USA). Rev. Palaeobot. Palynol. 14 (3/4), 217-285.

Srivastava, S. K. 1975: Maastrichtian microspore assemblages from the interbasaltic lignites of Mull, Scotland. Palaeontographica B 150 (5-6), 125-156.

Stanley, E. A. 1965: Upper Cretaceous and Paleocene plant microfossils and Paleocene Dinoflagellates and Hystrichosphaerids from northwestern South Dakota. Bull. Amer. Paleont. 49 (222), 179-384.

Tarling, D. H. \& Gale, N. H. 1968: Isotopic dating and palaeomagnetic polarity in the Faeroe Islands. Nature, 218, 10431044.

Thomson, P. W. \& Pflug, H. 1953: Pollen und Sporen des mitteleuropäischen Tertiärs. Palaeontographica B 94 (1-4), $138 \mathrm{pp}$.

Trevisan, L. 1967: Pollini fossili del Miocene superiore nei Tripoli del Gabbro (Toscana). Palaeontographica Italica, LXII (N. ser. XXXII), 1-78.

Tschudy, R. H. 1973: Stratigraphic distribution of significant Eocene palynomorphs of the Mississippi embayment. Geol. Surv. Prof. Paper 743-B, 24 pp.

Van Geel, B., Hallewas, D. P. \& Pals, J. P. 1983: A Late Holocene deposit under the Westfriese Zeedijk near Enkhuizen (Prov. of Noord-Holland, The Netherlands): Palaeoecological and archaeological aspects. Rev. palaeobot. Palynol., 38, 269-335.

Waagstein, R., Hald, N., Jørgensen, O., Nielsen, P. H., NoeNygaard, A., Rasmussen J. \& Schönharting, G. 1984: Deep drilling on the Faeroe Islands. Bull. geol. Soc. Denmark, 32, 133-138.

Wilson, L. R. \& Webster, R. M. 1946: Plant Microfossils from a Fort Union Coal of Montana. American Jour. Botany 33 (4), 271-278.

Wilson, M. A. 1978: Palynology of three sections across the uppermost Cretaceous/Paleocene boundary in the Yukon Territory and District of Mackenzie, Canada. Palaeontographica $B, 166$ (4-6), 99-183.

Wodehouse, R. P. 1933: Tertiary pollen. II, The oil shales of the Eocene Green River formation. Torrey Bot. Club Bull. 60, 479-524.

\section{Explanation of plates}

All photographs on plates 1 to 7 are magnified 1000 times. Slide references are in brackets: sample number/preparation number-slide number. 


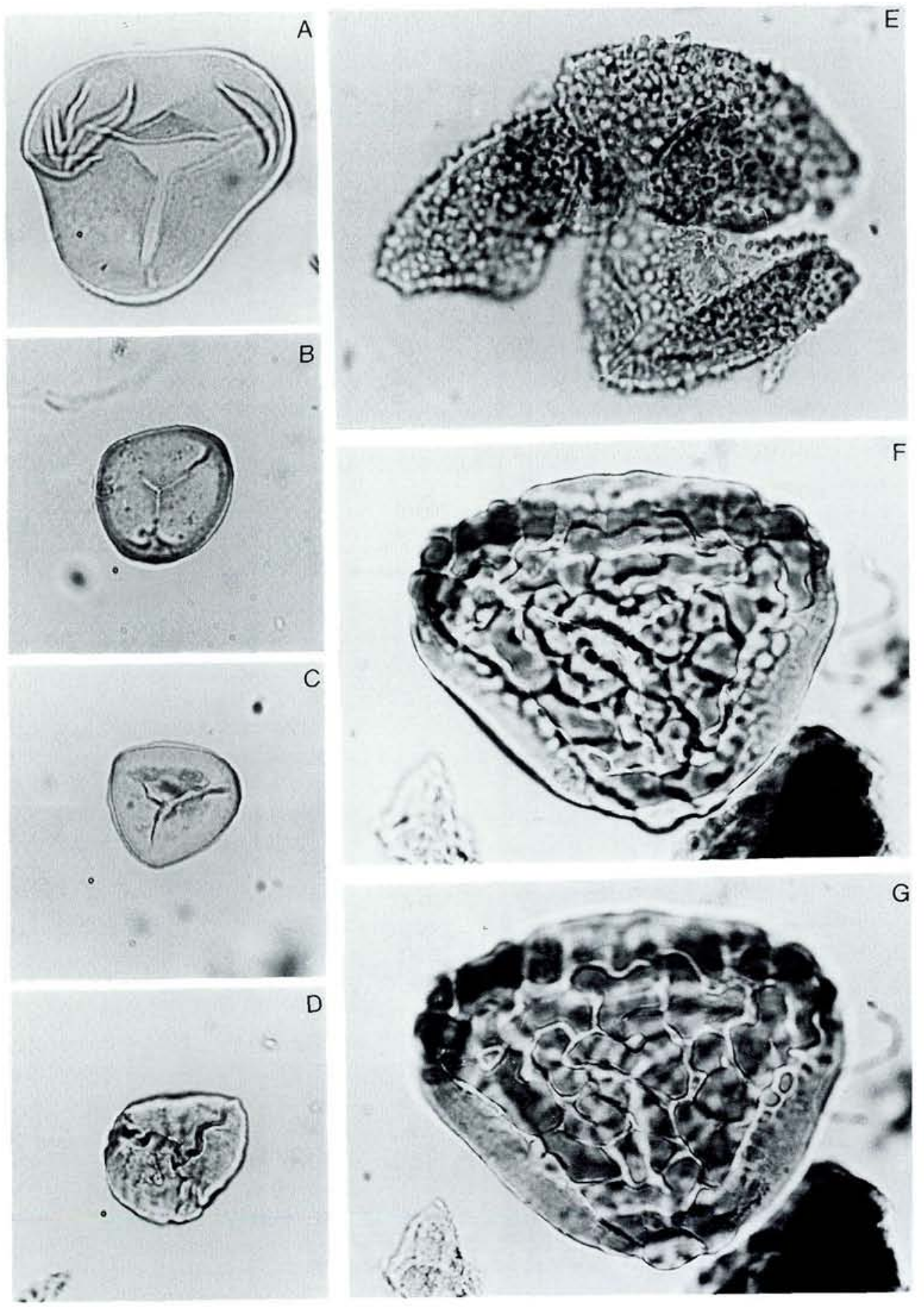

Plate 1:

A: Deltoidospora diaphana Wilson \& Webster 1946, (05/2-1)

B: Stereisporites sp, (13/2-1)

C: cf. Stereisporites sp., $(05 / 2-1)$

D: Undulatisporites sp., $(10 / 2-1)$

E: Baculatisporites gemmatus Krutzsch 1959, (13/2-1)

F-G: Polypodiaceoisporites marxheimensis (Mürriger \& Pflug ex Thomson \& Pflug) Krutzsch 1959, (10/2-1) 


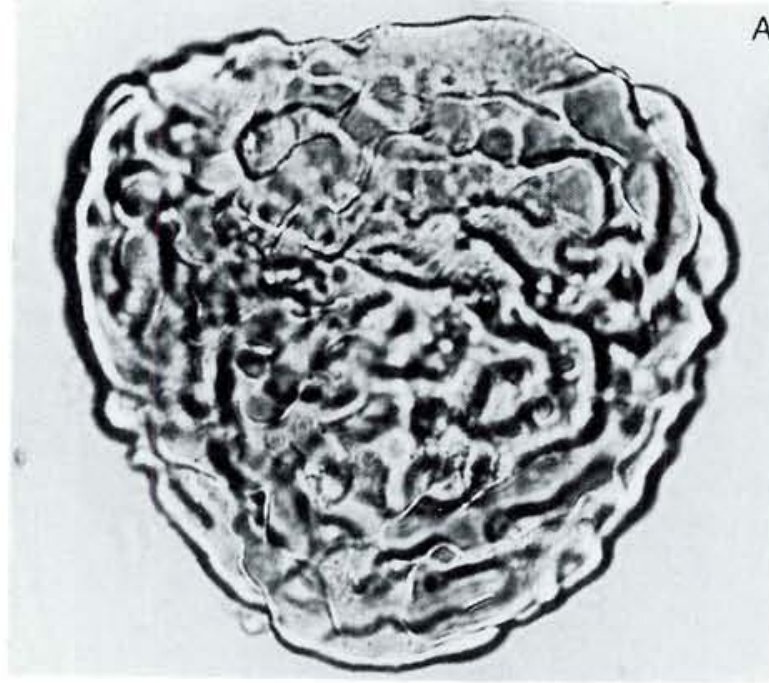

A
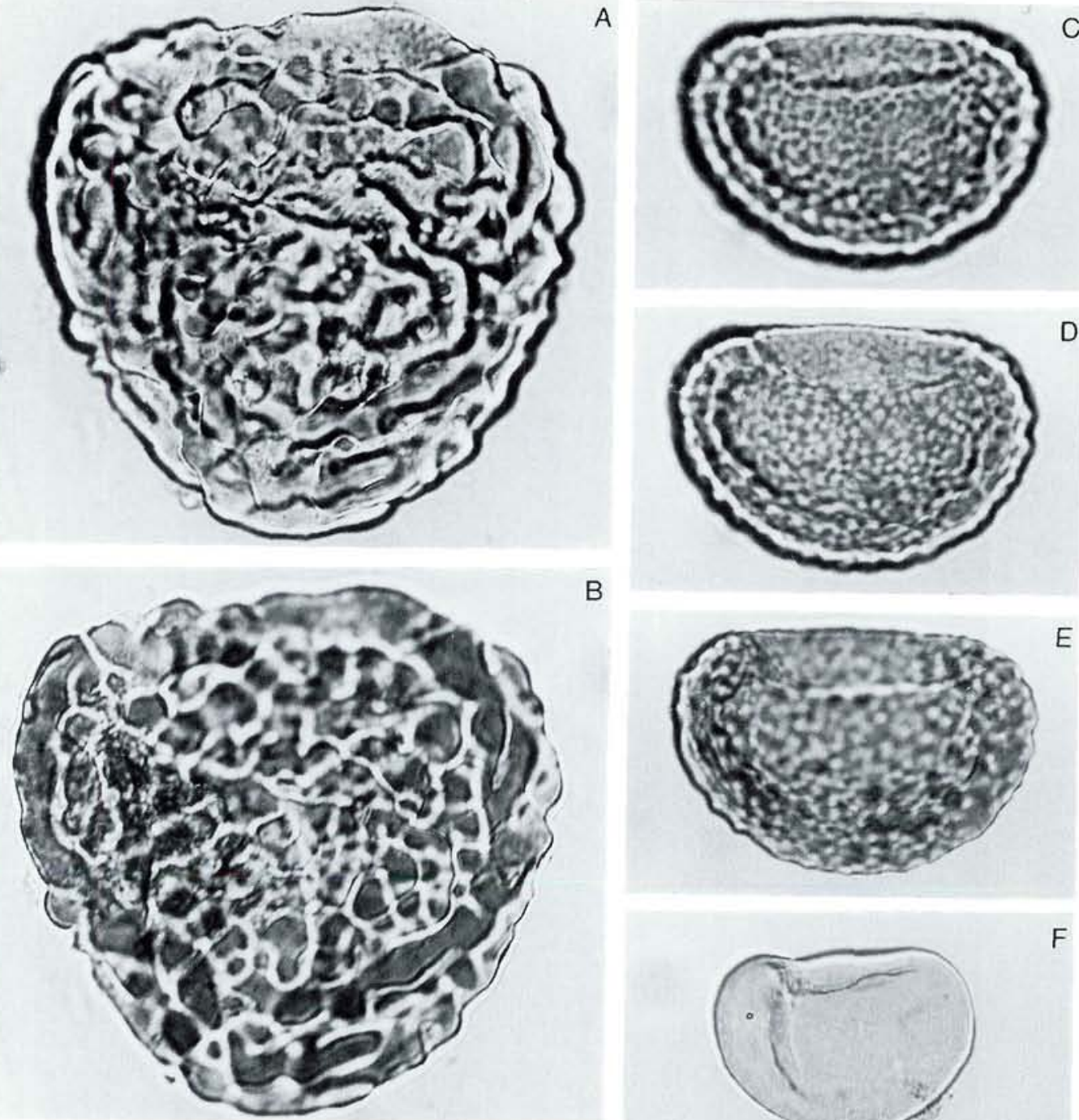

B
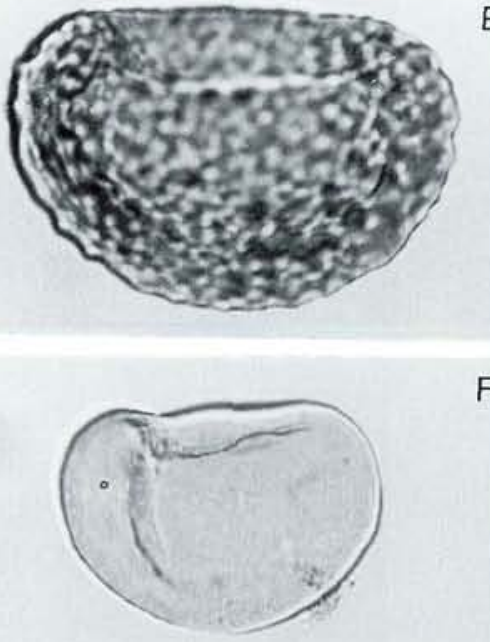

F

$H$
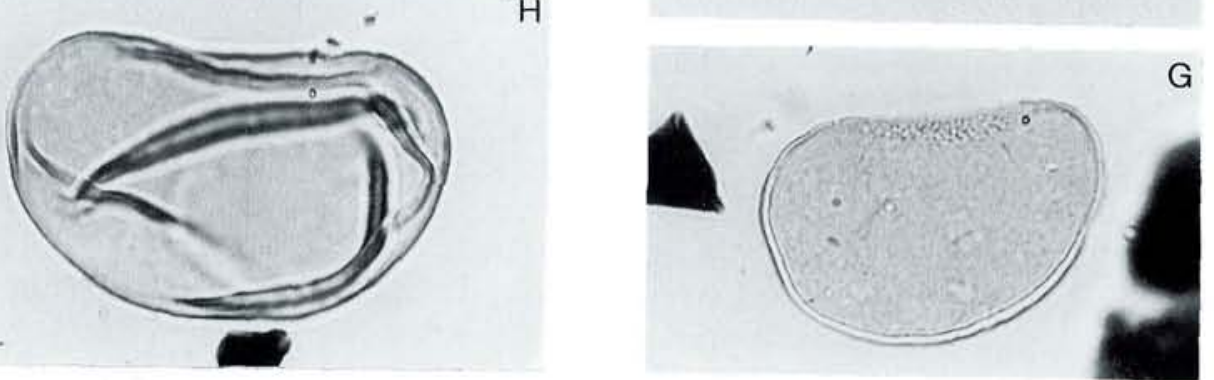

Plate 2:

A-B: Trilites multivallatus (Pflug) Krutzsch 1959, (10/2-2)

C-E: Reticuloidosporites dentatus Pflug 1953, (05/2-1)

F: Laevigatosporites haardtii (Potonié \& Venitz) Thomson \& Pflug 1953, (09/2-2).

G: Laevigatosporites haardtii (Potonié \& Venitz) Thomson \& Pflug 1953, (05/2-1).

H: Laevigatosporites cf. haardtii (Potonié \& Venitz) Thomson \& Pflug 1953, (05/2-1) 
A
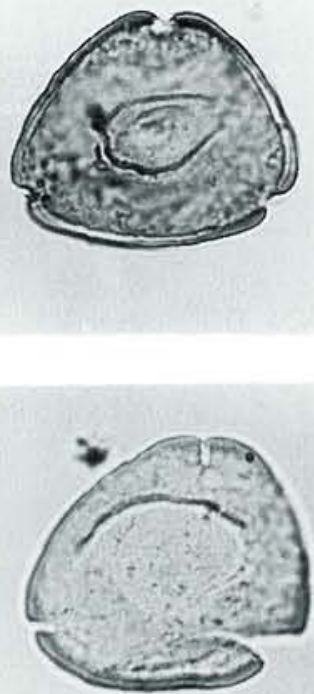

$+4$

G

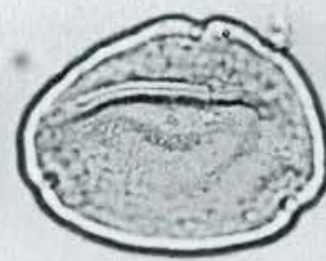

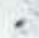

D

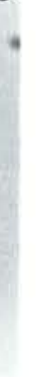

G
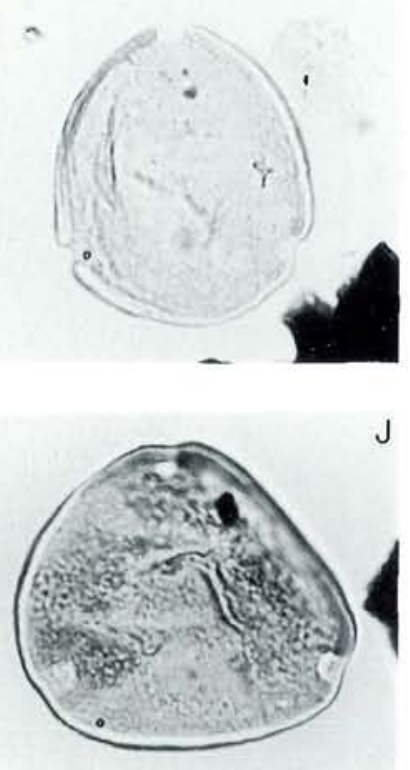

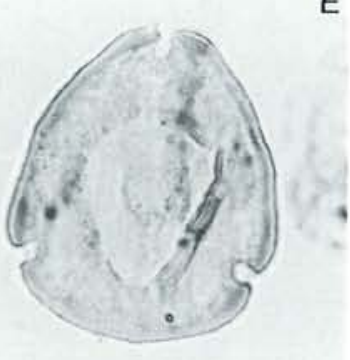

B

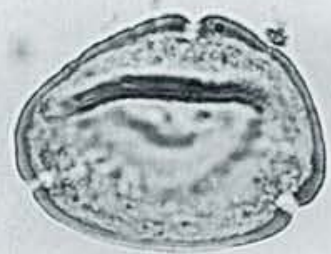

4

E

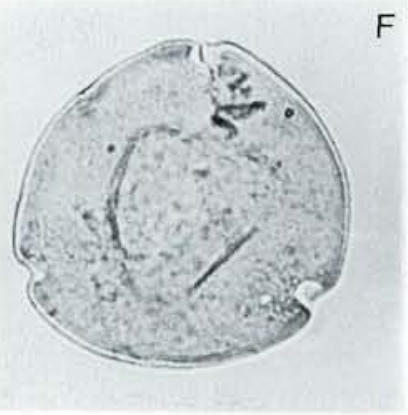

$\mathrm{H}$

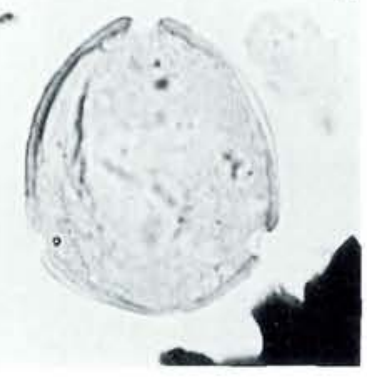

K

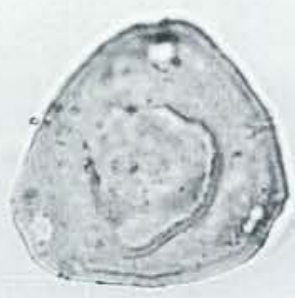

C

\section{F}
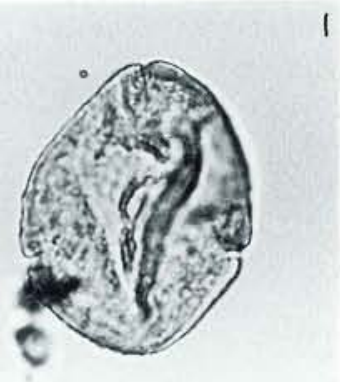

L

Plate 3:

A: Momipites amplus (Leffingwell) Nichols 1973, (08/2-3)

B-D: Momipites amplus (Leffingwell) Nichols 1973, (10/2-1)

E: Momipites amplus (Leffingwell) Nichols 1973, (13/2-1)

F: ?Momipites amplus (Leffingwell) Nichols 1973, (11/2-1)

G-H: Momipites coryloides Wodehouse 1933, (05/2-1)

I: Momipites sp. 1, (11/2-1)

J: Caryapollenites type 1, (11/2-1)

K: Caryapollenites type 2, (09/2-1)

L: Caryapollenites type 3, $(09 / 2-1)$ 


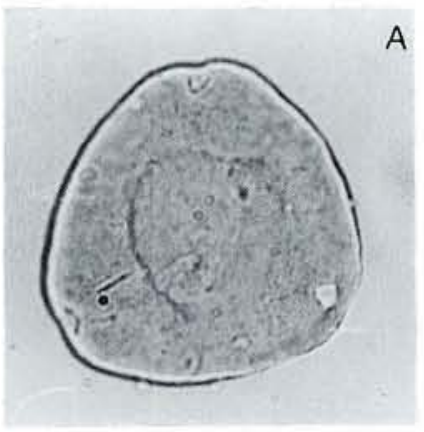

A

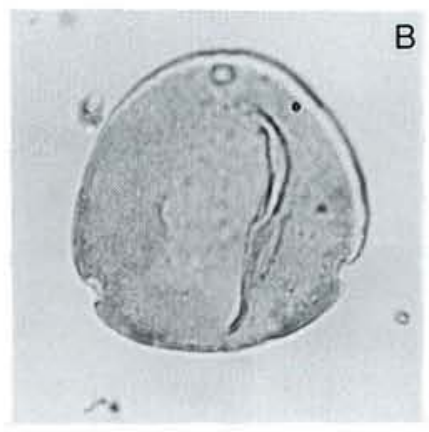

C

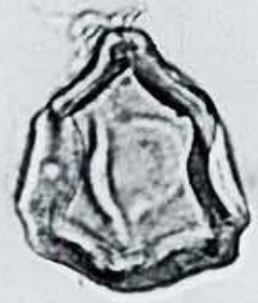

B

D
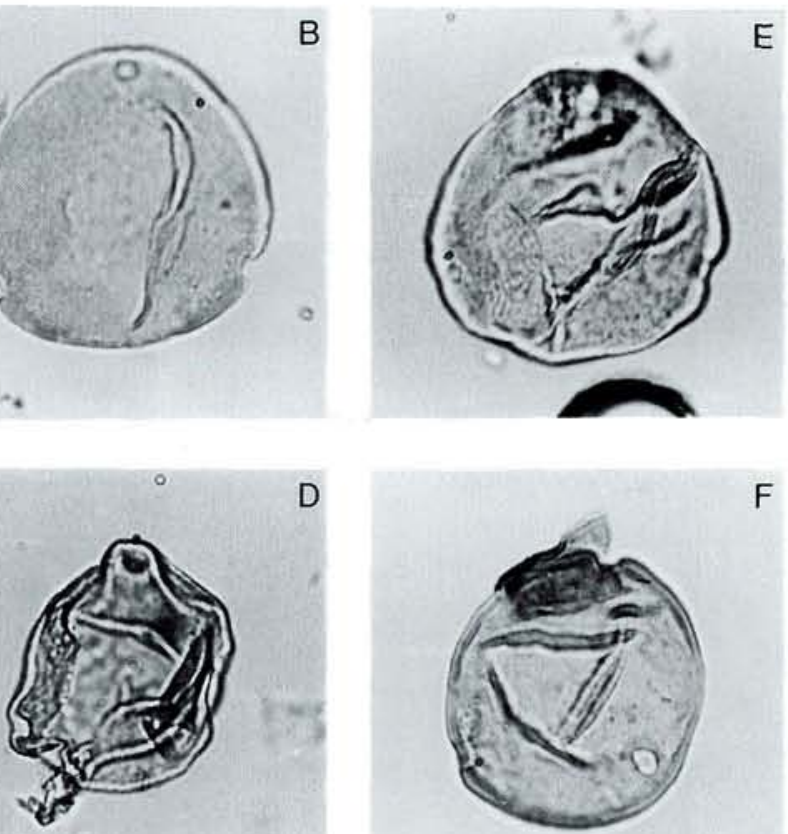

F

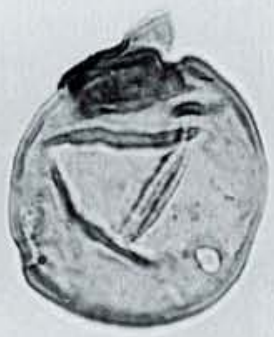

G
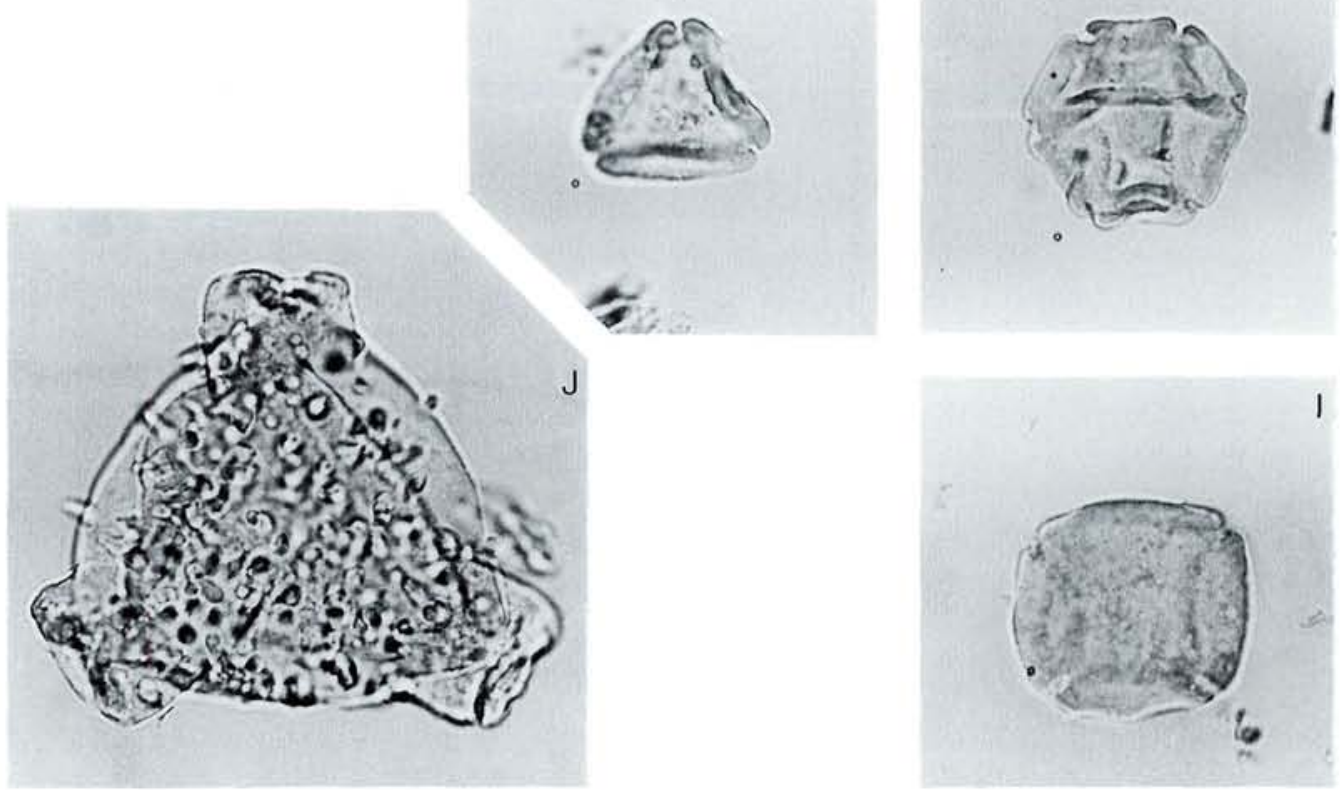

Plate 4:

A: Caryapollenites type 4, (16/2-3)

B: Caryapollenites type 5, (05/2-1)

C: Trivestibulopollenites betuloides Pflug 1953, (14/2-3)

D: Trivestibulopollenites betuloides Pflug 1953, (05/2-1)

E: Cf. Caryapollenites type $6,(10 / 2-1)$

F: Cf. Caryapollenites type 6, (13/2-1)

G: "Alnipollenites" trina (Stanley) Norton 1969, (09/2-1)

$\mathrm{H}$ : Alnipollenites verus Potonié 1931, (10/2-1)

I: Alnipollenites sp., (09/2-2)

J: Montanapollis sp., (29/2-4) 

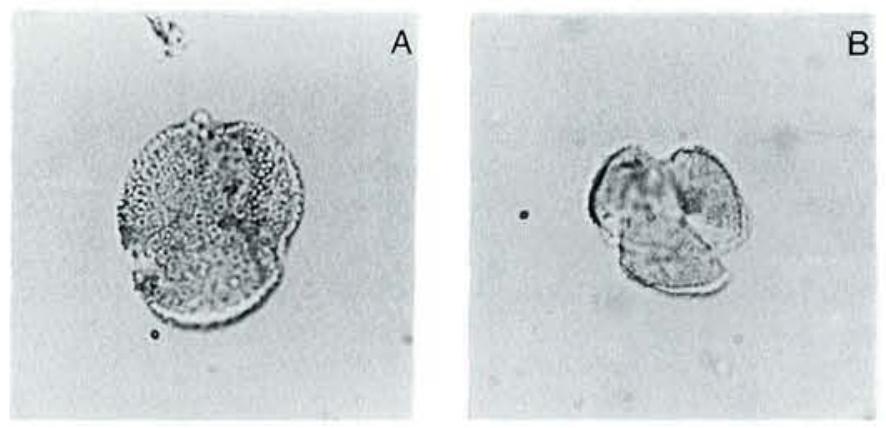

$B$

C
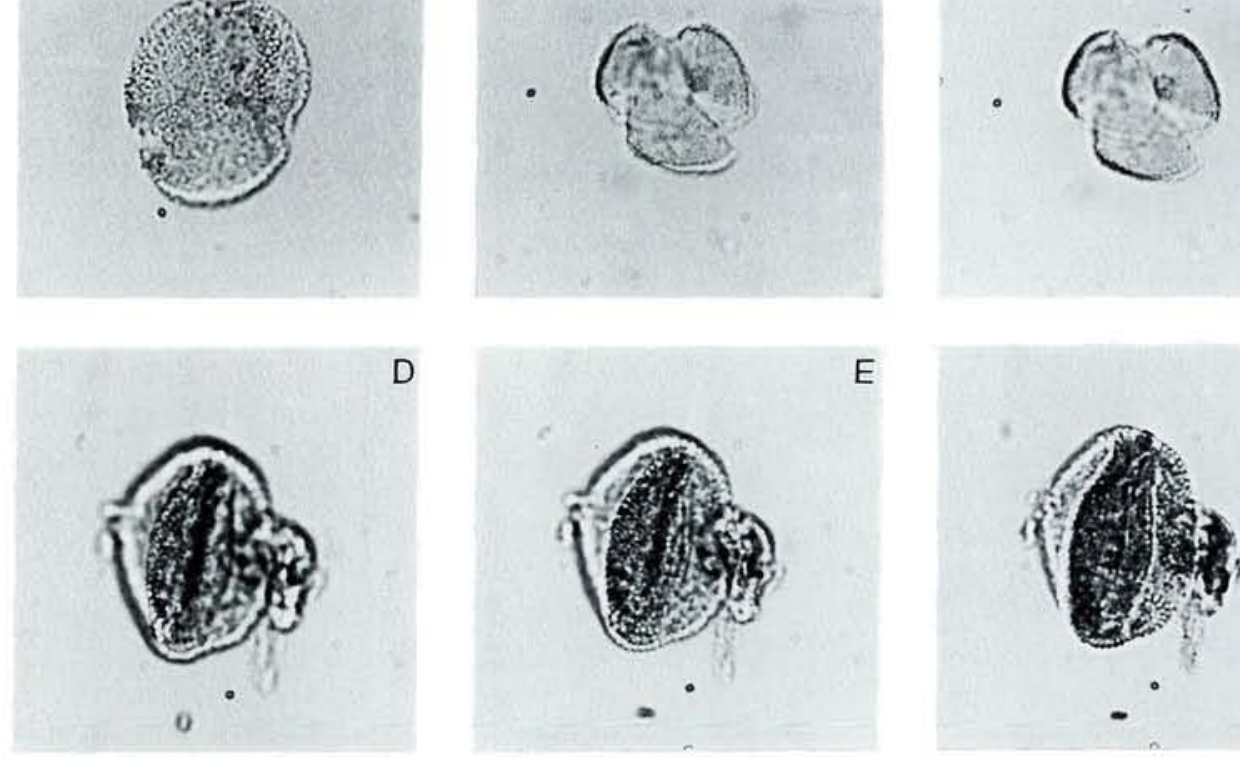

E
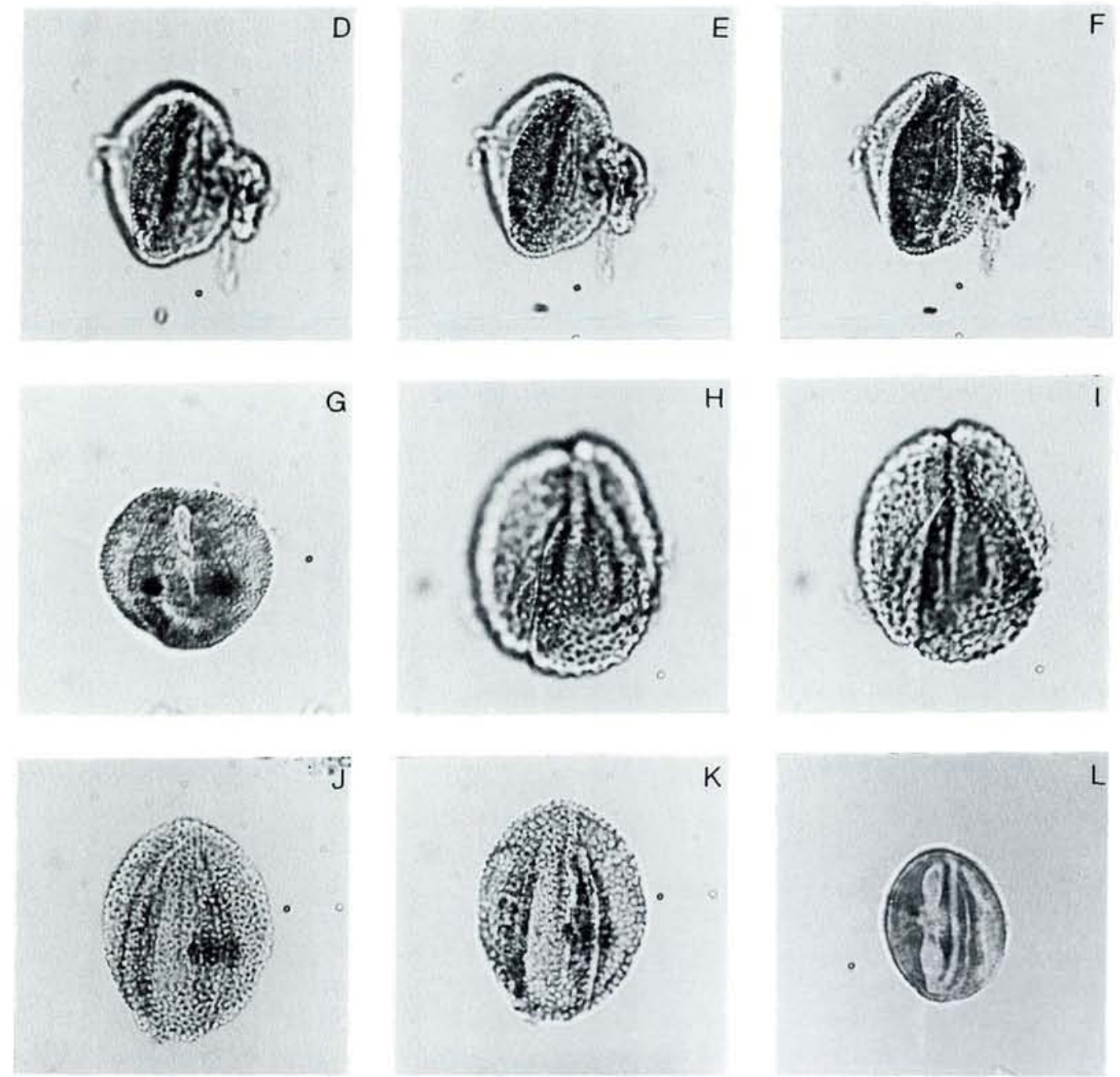

j

$\mathrm{K}$

Plate 5:

A: Tricolpites hians Stanley 1965, (09/2-2)

B-C: Tricolpites parvus Stanley 1965, (05/2-1)

D-F: Tricolpopollenites sp. 1, (11/2-1)

G: Tricolpopollenites sp. 2, (09/2-1)

H-I: Tricolpopollenites sp. 3, (14/2-1)

J-K: Tricolporopollenites baculoferus Pflug 1953, (29/2-4)

L: Tricolporopollenites villensis (Thomson) Thomson \& Pflug 1953, (09/2-1) 

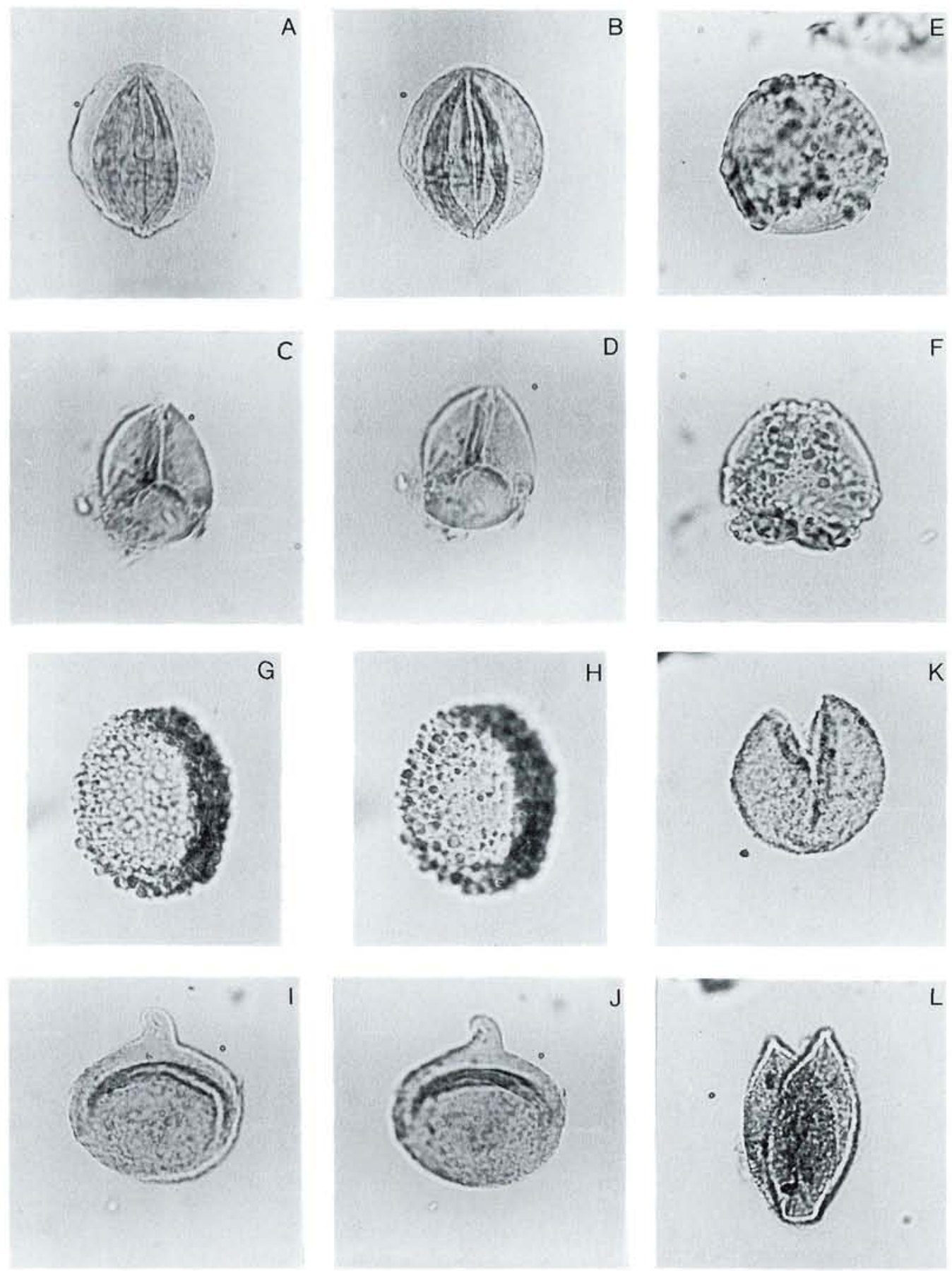

Plate 6:

A-B: Tricolporopollenites sp., (29/2-1)

C-D: Cupanieidites sp., (09/2-3)

E-F: Phaseoliidites stanleyi Elsik 1968, (10/2-1)

G-H: Sciadopityspollenites serratus (Potonié \& Venitz) Raatz 1937, (05/2-1)

I-J: Sequoiapollenites paleocenicus Stanley 1965, (16/2-2)

K: Inaperturopollenites hiatus (Potonié) Thomson \& Pflug 1953, (11/2-1)

L: Inaperturopollenites hiatus (Potonie) Thomson \& Pflug 1953, (09/2-2) 


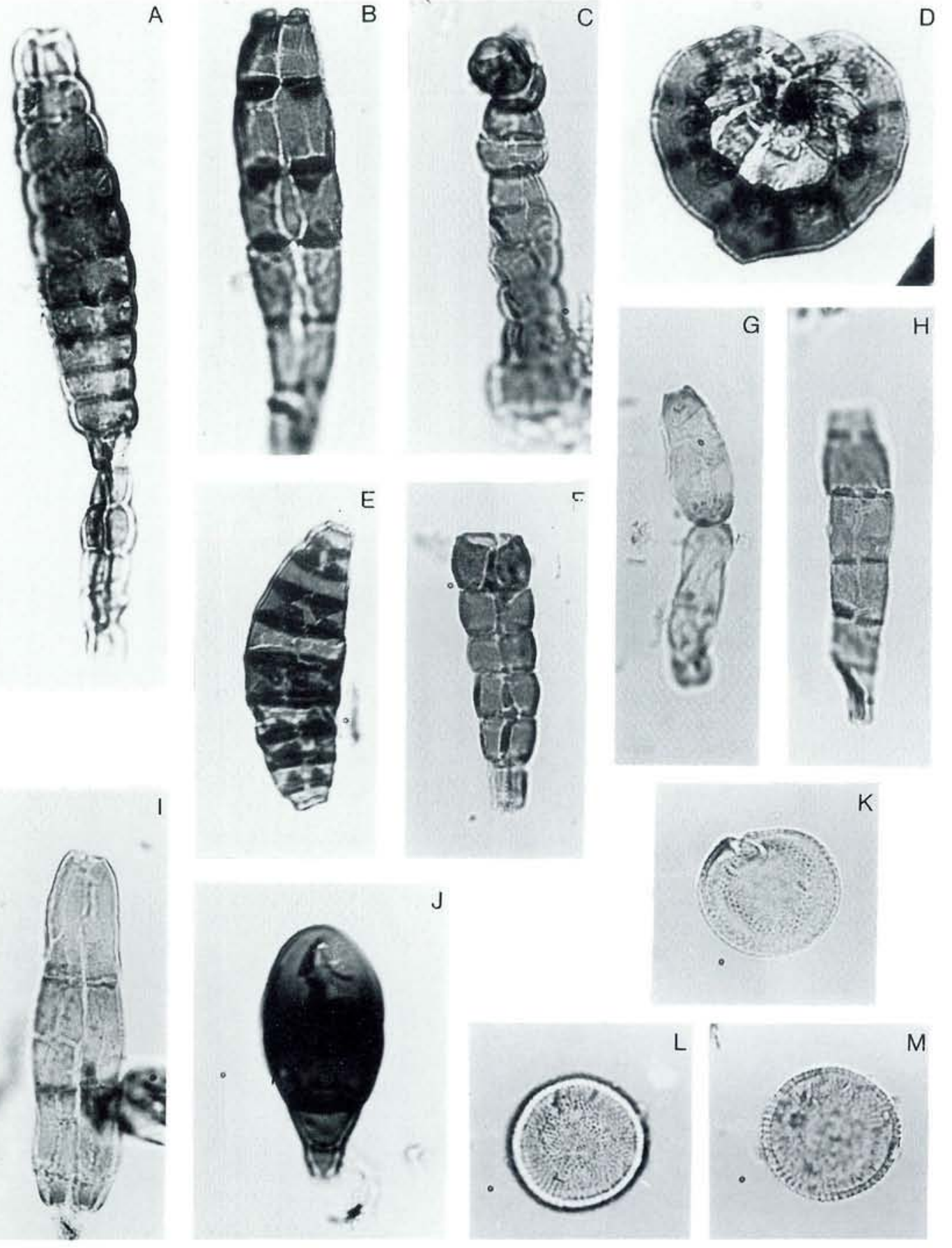

Plate 7:

A-C \& E-I: Multicellaesporites spp.; A, B, G, and I slide 09/2-2; C, F, and H slide 09/2-1; E slide 29/2-1

D: Pesavis tagluensis Elsik \& Jansonius 1974, (29/2-3)

J: Brachysporisporites Lange \& Schmidt 1971, (11/2-1)

K-M: Sigmopollis sp., (10/2-1) 